\title{
FERMAT'S DILEMMA: WHY DID HE KEEP MUM ON INFINITESIMALS? AND THE EUROPEAN THEOLOGICAL CONTEXT
}

\author{
JACQUES BAIR, MIKHAIL G. KATZ, AND DAVID SHERRY
}

\begin{abstract}
The first half of the 17th century was a time of intellectual ferment when wars of natural philosophy were echoes of religious wars, as we illustrate by a case study of an apparently innocuous mathematical technique called adequality pioneered by the honorable judge Pierre de Fermat, its relation to indivisibles, as well as to other hocus-pocus. André Weil noted that simple applications of adequality involving polynomials can be treated purely algebraically but more general problems like the cycloid curve cannot be so treated and involve additional tools-leading the mathematician Fermat potentially into troubled waters. Breger attacks Tannery for tampering with Fermat's manuscript but it is Breger who tampers with Fermat's procedure by moving all terms to the left-hand side so as to accord better with Breger's own interpretation emphasizing the double root idea. We provide modern proxies for Fermat's procedures in terms of relations of infinite proximity as well as the standard part function.

Keywords: adequality; atomism; cycloid; hylomorphism; indivisibles; infinitesimal; jesuat; jesuit; Edict of Nantes; Council of Trent 13.2
\end{abstract}

\section{Contents}

1. Introduction

1.1. A re-evaluation

1.2. Procedures versus ontology

1.3. Adequality and the cycloid curve 5

1.4. Weil's thesis 6

1.5. Reception by Huygens 8

1.6. Our thesis 9

1.7. Modern proxies 10

1.8. Infinitesimals, adequality, and standard part 11

1.9. Transcription of Fermat's argument 12

1.10. Text sent to Descartes

1.11. Original Latin 13 
1.12. Fermat's Sur la même méthode 14

2. Reductive readings $\quad 15$

2.1. Reductive readings of adequality: Breger 15

2.2. Fermat's letter; enfin 16

2.3. Did Tannery tamper with Fermat's manuscript? $\quad 17$

2.4. Breger's judgment of Tannery 18

2.5. Cherry-picked numerology 20

2.6. Breger's wrong move 20

2.7. Triumvirate bias 22

2.8. Breger's equivocation 24

2.9. Fermat versus Breger 24

2.10. A self-inflicted textual difficulty 25

2.11. Reductive readings of adequality: Felgner 26

2.12. Reductive readings of adequality: Barner 26

3. Historical setting 27

3.1. Salient historical points $\quad 27$

3.2. The 17th century scientific context 29

4. Social, religious, and military 17th century background 31

4.1. Bans on indivisibles 31

4.2. "Vide intégral" 32

4.3. Grassi and Guldin $\quad 33$

4.4. War and pope 34

4.5. Scheiner vs Galileo 34

4.6. Degli Angeli in Italy 35

4.7. Gregory's departure from Italy 36

4.8. Council of Trent, Galileo, and G3 37

4.9. Document EE291 on Galileo's atomism 38

4.10. Concerning Canon $13.2 \quad 39$

4.11. Old and new heresy 40

4.12. Reception of Galileo trial in France 40

5. Fermat at Castres and conclusion 41

5.1. Jean de l'Hospital, (ancient) Conseiller 41

5.2. Fermat's poem 42

5.3. Academy of Castres 42

5.4. The lesson of the Marranos of Toulouse 43

Acknowledgments 44

References 44 
Father Bertet sayth your Bookes are in great esteeme, but not to be procured in Italy. (Collins to Gregory)

${ }^{a}$ See further in note 34 .

\section{INTRODUCTION}

In his review of Pietro Redondi's book on Galileo, Egidio Festa writes: "Avec la sentence du Tribunal du Saint-Office, la fracturequi allait se révéler irréversible-entre vérité de science et vérité de foi apparut au grand jour"'1] [Festa 1991, p. 94]. Whatever the merits of Festa's generalisation concerning a conflict opposing science and catholicism (surely the pagan Aristotelian hylomorphism had to give way to make room for the emerging atomist science), many modern studies have focused on such tensions in the context of Galileo and other scientists (including the jesuit condemnation of indivisibles in the works of Galileo, Cavalieri, and others). The scientific community in France closely followed the 1633 trial; Pierre Gassendi's role is analyzed in [Festa 1991]; on Carcavy and Mersenne see Section 4.12.

Mathematicians are sometimes thought to have been affected to a lesser extent, though well-known examples include Cavalieri and degli Angeli. In this text we examine evidence that doctrinal factors may have affected the presentation of the work of a mathematician not usually thought of as involved in the Galilean controversy: the honorable judge Pierre de Fermat.

Fermat's jesuit friend Antoine de Lalouvère at Toulouse was a "declared enemy" of indivisibles [Descotes 2015, p. 267]. Had Lalouvère expressed similar sentiments about them to Fermat as he did in his mathematical works, it would have provided little encouragement for Fermat to be overly explicit concerning the foundation of his method of adequality.

Fermat's professional activities at the Parliament of Toulouse included occasional stints at the Chambre de l'Édit at a nearby town of Castres. The relevance of the Chambre specifically is the fact that it was the organ of the Parliament that dealt with interdenominational quarrels (mainly of a pecuniary type), with judges split evenly between

\footnotetext{
1 "Following the verdict of the Tribunal of the Holy Office, the split-which would prove to be irreversible-between the truth of science and the truth of faith appeared in broad daylight."
} 
catholics and protestants. A key disagreement between catholics and protestants concerned the interpretation of the eucharist and its relation to atomism and kindred scientific doctrines like indivisibles and infinitesimals.

Due to the sensitive nature of his engagement at Castres, Fermat may have found it risky to speak freely of the nature of quantities involved in his technique of adequality. For his part, jesuit Tacquet claimed that one must destroy the theory of indivisibles (if Euclidean geometry is to be saved). If so, legitimate questions could arise concerning its practitioners' soundness of judgment and their fitness to judge cases that come before all-powerful Parliaments.

1.1. A re-evaluation. A re-evaluation of Fermat's technique of adequality and its place in the history of mathematics involves at least three components, which we describe respectively as the weak, standard, and strong theses.

(1) (weak thesis) the fact itself that Fermat refrained from elaborating in detail on the foundations of his technique, and specifically refrained from speculating on the nature of his $E$ used in the technique, does not constitute evidence toward a hypothesis that the technique was a purely algebraic one, due to professional and religious constraints Fermat was operating under, that would have made any such speculations reckless as far as his professional career was concerned.

(2) (standard thesis) We challenge the view adopted by some scholars working in a default Weierstrassian interpretive scheme, that Fermat used a purely algebraic technique unrelated to any notion of approximation or to infinitesimals. We argue that internal evidence in Fermat's work on the cycloid, on integration, and elsewhere points to a contrary conclusion (see Weil's thesis in Section 1.4). While Fermat may speak of his $E$ cautiously as being an arbitrary quantity, in his actual mathematical practice he exploits it as an arbitrarily small quantity that can be discarded in certain calculations.

(3) (strong thesis) We argue that the procedures of Fermat's work on maxima and minima as well as tangents, centers of gravity, and refraction find better proxies in the procedures of Robinson's infinitesimal-enriched framework [Robinson 1966] than in traditional Weierstrassian frameworks stripped of infinitesimals, just like the procedures of Gregory, Leibniz, Euler, Cauchy, and others. 
The present article deals mainly with arguing thesis (1). Evidence toward thesis (2) appears in Sections 1.3 and following. Evidence toward thesis (3) appears in Section 1.92 The thesis that Fermat's procedures are more akin to modern infinitesimal theories than to classical Weierstrassian analysis is developed in Cifoletti 1990] in the context of the Lawvere-Kock-Reyes framework; see Kock 2006.

1.2. Procedures versus ontology. Cifoletti seeks to justify "[l]e fait de juxtaposer deux fragments de théories mathématiques séparés par plus de trois cent cinquante ans" Cifoletti 1990, p. 4]. We would like to add the following two points to her arguments.

(A) Traditionally trained historians of mathematics apply conceptual frameworks deriving from modern Weierstrassian foundations, separated from Fermat by 250 years, in order to interpret Fermat; thus, the interpretation in [Barner 2011, p. 17] is explicitly stated to be based on an implicit function theorem of Ulisse Dini (1845-1918).

(B) The procedure versus ontology dichotomy enables us to seek proxies for Fermat's techniques while acknowledging the difference between ontological foundations of pre-Weierstrassian mathematics and modern mathematics, whether set-theoretic (as in the case of Weierstrass and Robinson) or category-theoretic (as in the case of Lawvere) 3 On modern proxies see further in Section 1.7.

1.3. Adequality and the cycloid curve. Fermat treated numerous problems concerning maxima and minima as well as tangents to curves using a procedure (more precisely, a cluster of procedures) called adequality. Fermat's work became known mainly through private letters to correspondents like Carcavy and Mersenne, and was eventually popularized through inclusion in a book by Pierre Hérigone Cifoletti 1990, p. 2].

A typical application involves finding the maximum of an expression involving $x$ (Fermat used " $A$ ") that we will denote in modern notation by $p(x)$. Fermat compared $p(x)$ and $p(x+E)$ and after doing algebra to eliminate common terms, he would form a relation (adequality) among terms divisible by $E$. He would then cancel out a factor of $E$

\footnotetext{
${ }^{2}$ Cf. [Katz et al. 2013], Bascelli et al. 2014, Section 3], Błaszczyk et al. 2017, Section 4].

${ }^{3}$ These two themes were explored more fully in recent articles in Erkenntnis Katz-Sherry 2013, HOPOS Bascelli et al. 2016, Journal for General Philosophy of Science [Bair et al. 2017], and elsewhere.
} 
and then discard any remaining terms in $E$ to obtain the answer (a more detailed example appears in Section [1.9). Since the relation between $p(x)$ and $p(x+E)$ is not one of true equality, Fermat referred to it as adequality.

The term adequality originates with Diophantus' $\pi \alpha \rho \iota \sigma o ́ \tau \eta \varsigma$ (meaning approximate equality) and $\pi \alpha ́ \rho \iota \sigma o \varsigma$ rendered as adaequo in Bachet's translation of Diophantus' Arithmetic, with which Fermat was intimately familiar. In the text sent to Descartes in the late 1630s Fermat explicitly names Diophantus as the source of the term: "Adaequentur, ut loquitur Diophantus" 5 [Fermat 1891, p. 133].

For a transcendental curve like the cycloid (see e.g., Cifoletti 1990, p. 70]), Fermat solved the problem of finding the tangent line at an arbitrary point of the curve as follows (see [Fermat 1896, p. 144]). Start with the defining equation of the cycloid (Fermat refers to such an equation as la propriété spécifique de la courbe). Consider the tangent line (to be determined) at a point $\mathrm{R}$ of the curve. Choose a nearby point $\mathrm{N}$ on the tangent line. Denote by $\mathrm{D}$ and $\mathrm{E}$ respectively the projections of $\mathrm{R}$ and $\mathrm{N}$ onto a suitable axis. Denote by $E$ the distance between the points $\mathrm{D}$ and E. Substitute the point $\mathrm{N}$ into the defining equation of the cycloid as if it satisfied the latter (hence not equality but adequality), and proceed with the steps involving cancellations of the quantity $E$; see [Katz et al. 2013, Section 5] for details 6

Since the cycloid is a transcendental curve, it would be difficult to interpret Fermat's solution as a purely algebraic procedure involving a formal symbol $E$, as already noted by André Weil:

At first Fermat applies the method only to polynomials, in which case it is of course purely algebraic; later he extends it to increasingly general problems, including the cycloid [Weil 1973, p. 1146].

1.4. Weil's thesis. We will elaborate Weil's remark cited above as the following principle:

\footnotetext{
${ }^{4}$ To a modern reader familiar with the calculus the procedure is reminiscent of quotients of increments occurring in the definition of the derivative but the period under discussion precedes the calculus of Newton and Leibniz.

5 "[Let there be] adequated, to speak like Diophantus" (here we use adequate as a verb-rather than as an adjective-in a neologism aiming to convey the meaning of the Latin). See further in Section 1.11.

${ }^{6}$ Herbert Breger attempts to account for Fermat's treatment of the cycloid without mentioning any notion of smallness but ends up falling back on the condition "if the point E is not too far away of the point D, then..." Breger 1994, p. 206]. Breger's biased criticism of Paul Tannery's Fermat scholarship is dealt with in Section 2.3. Breger's flawed rendering of Fermat's method is dealt with in Section 2.6.
} 
Weil's thesis: simple applications of Fermat's method that involve polynomials can be treated purely algebraically, but more general problems (like the cycloid) cannot be so treated and involve tools that of a more geometric or analytic flavor 7

Approximate equality similarly plays a role in Andersen's interpretation of Fermat's application of adequality to derive Snell's law of refraction. The procedure involves discarding second-order terms in $E$ twice Andersen 1983, p. 55]. Such a procedure is only meaningful for small $E$ when higher-order terms are negligible compared to $E$ itself. Thus Fermat's treatment of the cycloid and Snell's law furnishes textual evidence that his use of $E$ relies on it being small. 8

Mahoney assumes matter-of-factly that Fermat used infinitesimals 9 at least in his method of quadrature:

Especially where, in his mature method of quadrature, Fermat began to operate with infinitesimals and limit procedures, the reversion to synthesis became, as mathematicians from Newton to Cauchy were to find, far from easy. Mahoney 1994, p. 47]

Scholars ranging from Sabetai Unguru to André Wei 10 take it for granted that Fermat's technique involves approximate equality. Thus, Unguru writes in reference to Fermat's method of tangents:

This computation involved... the concept of 'adequality' (taken over from Diophantus), according to which. . . the two ordinates of (1) an arbitrary point on the tangent other than the point of tangency and (2) the corresponding point on the curve determined by the intersection of that ordinate and the curve were assumed to be 'adequal' Unguru 1976, p. 776].

Since the point on the tangent line and the corresponding point on the curve (with the same ordinate) are in general unequal, we see that

\footnotetext{
${ }^{7}$ Though apparently straighforward, Weil's thesis has been resisted by a small number of Fermat scholars recently; see Section 2.1.

${ }^{8}$ We therefore reject Breger's claim that "[t]he idea that the mathematically conservative Fermat ... is supposed to have calculated using infinitesimals is a bold hypothesis for which there are no textual proofs" Breger 2013, p. 23].

${ }^{9}$ Without referring to them explicitly as infinitely small, of course. We should mention that Mahoney's interpretation of Fermat's method of adequality is incompatible with ours.

${ }^{10}$ The pair may be familiar to the reader as the leaders of opposing schools in the debate over geometric algebra; see e.g., Weil 1978.
} 
according to Unguru's reading, setting them adequal involves an approximate equality. Unguru comments further:

Initially inspired by Archimedes' treatment in 'On spirals', Fermat later improved and generalized his method of quadrature by means of a new meaning attached to the concept of 'adequality', now taken to stand for 'approximate' or 'limiting' equality. (ibid.)

Similarly, Weil notes that Diophantus uses the Greek term

to designate his way of approximating a given number by a rational solution to a given problem (cf. e.g. Dioph. V.11 and 14) [Weil 1984, p. 28]. (emphasis added)

According to Weil's interpretation, approximation is inherent to the meaning of the original Greek term $\pi \alpha \rho \iota \sigma o ́ \tau \eta \varsigma$.

Breger appears to recognize that Leibniz understood Fermat's method to be based on infinitesimals, but claims that "the texts available to Leibniz contained grave contradictions and were hardly suitable for a clear understanding of the method" [Breger 2013, p. 24]. Yet Breger acknowledges that Leibniz may have had access to the 1679 Varia Opera edition of Fermat's collected works (ibid., note 28) and moreover that Huygens and Leibniz corresponded about the Opera Omnia edition (ibid., note 31 ).

1.5. Reception by Huygens. The thesis we develop in the present text does not depend on considering Fermat's $E$ as necessarily being infinitely small. Even if one adopts a purely algebraic interpretation of Fermat's techniques including quadrature and adequality (as is eminently possible for some of Fermat's simpler applications of adequality, as per Weil's thesis; see Section 1.4), one can still ask why Fermat, unlike his contemporaries like Keplen 11 and Galileo, chose not to work explicitly with the infinitely small.

Fermat offered little in the way of explanation of his method of adequality. What are the reasons for Fermat's evasiveness about the foundations of his method? Why did Fermat never clarify whether his $E$ were infinitely small or account for some of his methods in terms of indivisibles, as Kepler, Galileo, and Cavalieri did? While presenting

\footnotetext{
${ }^{11}$ Jean d'Espagnet was interested in the work of Robert Fludd (1574-1637), whom Kepler had attacked. That alone might have brought d'Espagnet to Kepler's books. While it is plausible that d'Espagnet's library at Bordeaux should have included Kepler's works, the question of Kepler's possible influence on Fermat's method is a subject of long-standing scholarly controversy exhaustively covered in Cifoletti 1990, pp. 40-60]. For a summary of Kepler's contribution to infinitesimal techniques of barrel measuring see Jongmans 2008.
} 
an interpretation of Fermat's method at the French academy, Huygens commented as follows:

Fermat est le premier homme que je sache qui ait établi une règle certaine pour déterminer les valeurs maximales et minimales dans les questions géométriques. En en recherchant le fondement qu'il n'a pas communiqué, etc. (Huygens cited in [Noël-Trompler 2003]) (emphasis added)

Most commentators agree with Huygens' sentiment. Huygens continued:

...j'ai trouvé en même temps de quelle manière cette règle peut être réduite à une brièveté remarquable, de sorte qu'elle s'accorde désormais avec celle donnée plus tard par l'honorable Hudde comme une partie de la règle plus générale et fort élégante qui s'appuie sur un tout autre principe. Cette dernière a été publiée par Fr. Van Schooten dans le recueil qui contient aussi les livres de Descartes sur la géométrie. Or, ma méthode d'examiner la règle de Fermat était la suivante... (Oeuvres complètes, 1940, tome 20). (ibid.)

Huygens' observation that Fermat did not provide an explanation of the foundation of his method is echoed by De Gandt:

Fermat et Roberval, pour des raisons très différentes, conservent une grande partie de leurs trésors dans leurs papiers personnels. [De Gandt 1992, p. 104]

Concerning Fermat's limited mathematical output, Spiesser writes:

[Fermat] s'en explique par le manque de temps, ... et par 'sa pente naturelle vers la paresse' (par exemple, Oeuvres II, p. 461). Ces arguments, dont le second relève quelque peu de la coquetterie, lui permettent également d'excuser son manque d'intérêt pour les expositions détail-

lées des preuves ... S Spiesser 2016, p. 297]

Spiesser's assessment of Fermat's claim of alleged paresse as a kind of coquetterie is right on target. We will therefore seek deeper reasons for his apparent evasiveness in explaining his method.

1.6. Our thesis. We shall argue that Fermat's reticence may have been due either to a deference to his contemporary catholic theologians including jesuits who were often opposed to atomism and indivisibles on doctrinal grounds, or to a possible fear of religious reprisals. If this 
is correct, then Fermat was in similar position to 17th century Italian mathematicians most of whom forsook indivisibles 12

1.7. Modern proxies. In this and the following sections we outline a modern formalisation of a relation of adequality and the associated procedures while keeping in mind the distinction between procedure and ontology outlined in Section 1.2. Readers already familiar with this set-theoretic justification of an infinitesimal-enriched continuum can skip to Section 1.8 .

We start with a construction (called an ultrapower) of a hyperreal extension $\mathbb{R} \hookrightarrow{ }^{*} \mathbb{R}$. Let $\mathbb{R}^{\mathbb{N}}$ denote the ring of sequences of real numbers, with arithmetic operations defined termwise. Then we have a totally ordered field * $\mathbb{R}=\mathbb{R}^{\mathbb{N}} / \mathrm{MAX}$ where "MAX" is a suitable maximal ideal. Elements of ${ }^{*} \mathbb{R}$ are called hyperreal numbers. Note the formal analogy between the quotient ${ }^{*} \mathbb{R}=\mathbb{R}^{\mathbb{N}} / \mathrm{MAX}$ and the construction of the real numbers as equivalence classes of Cauchy sequences of rational numbers. In both cases, the subfield is embedded in the superfield by means of constant sequences, and the ring of sequences is factored by a maximal ideal.

We now describe a construction of such a maximal ideal of $\mathbb{R}^{\mathbb{N}}$ exploiting a suitable finitely additive measure $\xi: \mathcal{P}(\mathbb{N}) \rightarrow\{0,1\}$ (thus $\xi$ takes only two values, 0 and 1$)$ taking the value 1 on each cofinite set 13 where $\mathcal{P}(\mathbb{N})$ is the set of subsets of $\mathbb{N}$. The ideal MAX consists of all "negligible" sequences $\left(u_{n}\right)$, i.e., sequences which vanish for a set of indices of full measure $\xi$, namely, $\xi\left(\left\{n \in \mathbb{N}: u_{n}=0\right\}\right)=1$. The subset $\mathcal{U}=\mathcal{U}_{\xi} \subseteq \mathcal{P}(\mathbb{N})$ consisting of sets of full measure $\xi$ is called a free ultrafilter (these can be shown to exist using Zorn's lemma).

Definition 1.1. The order on ${ }^{*} \mathbb{R}$ is defined by setting $\left[\left(u_{n}\right)\right]<\left[\left(v_{n}\right)\right]$ if and only if $\xi\left(\left\{n \in \mathbb{N}: u_{n}<v_{n}\right\}\right)=1$ or equivalently $\left\{n \in \mathbb{N}: u_{n}<\right.$ $\left.v_{n}\right\} \in \mathcal{U}$.

Example 1.2. An element $x \in \mathbb{R}$ is embedded in ${ }^{*} \mathbb{R}$ by means of the constant sequence with general term $x$. Let $v=\left[\left(v_{n}\right)\right] \in{ }^{*} \mathbb{R}$. Then $x$ satisfies $x<v$ if and only if $\left\{n \in \mathbb{N}: x<v_{n}\right\} \in \mathcal{U}$.

For a broader view of Robinson's framework see [Fletcher et al. 2017]. Minimal set-theoretic requirements for constructing a definable hyperreal line are analyzed in Herzberg et al. 2018.

\footnotetext{
${ }^{12}$ A possible exception is the work of Mengoli, cf. [Massa 1997, though Mengoli carefully avoided the language of indivisibles.

${ }^{13}$ For each pair of complementary infinite subsets of $\mathbb{N}$, such a measure $\xi$ "decides" in a coherent way which one is "negligible" (i.e., of measure 0) and which is "dominant" (measure 1).
} 
1.8. Infinitesimals, adequality, and standard part. Based on the set-theoretic construction of a hyperreal extension $\mathbb{R} \hookrightarrow^{*} \mathbb{R}$ given in Section 1.7, we introduce some terminology for dealing with infinitesimals.

Definition 1.3. An element $E \in{ }^{*} \mathbb{R}$ is called infinitesimal if for each positive $r \in \mathbb{R}$ one has $-r<E<r$.

Definition 1.4. Hyperreal numbers $a, b$ are said to be infinitely close, written

$$
a \approx b,
$$

if their difference $a-b$ is infinitesimal.

It is convenient also to introduce the following terminology and notation. We will use Leibniz's notation $\square 14$ Leibniz used the symbol to denote a notion of generalized equality "up to" a negligible term, though he did not distinguish it from the usual symbol "=" which he also used in the same sense.

Definition 1.5. Hyperreal numbers $a, b$ are said to be adequal, written

$$
a \sqcap b,
$$

if either $\frac{a}{b} \approx 1$ or $a=b=0$.

Example 1.6. We have $\sin x \sqcap x$ for infinitesimal $x$. While the relation $\sin x \approx x$ for infinitesimal $x$ is immediate from the continuity of sine at the origin (in fact both sides are infinitely close to 0), the relation $\sin x \sqcap x$ is a subtler relation equivalent to the computation of the first order Taylor approximation of sine.

The crucial observation is that unlike the relation $\approx$, the relation $\square$ has the following property of multiplicative invariance.

Theorem 1.7. The relation $\square$ is multiplicatively invariant in the sense that if polynomials (or more general expressions) $P$ and $Q$ satisfy $P \sqcap Q$ then also $\frac{P}{E} \sqcap \frac{Q}{E}$.

Proof. If $\frac{P}{Q} \approx 1$ then $\frac{P / E}{Q / E}=\frac{E P}{E Q}=\frac{P}{Q} \approx 1$, as well.

An element $u \in{ }^{*} \mathbb{R}$ is called finite if $-r<u<r$ for a suitable $r \in \mathbb{R}$. Let ${ }^{\mathfrak{h}} \mathbb{R} \subseteq{ }^{*} \mathbb{R}$ be the subring consisting of finite elements of $* \mathbb{R}$.

Theorem 1.8. There exists a function $\mathrm{st}:{ }^{\mathfrak{h}} \mathbb{R} \rightarrow \mathbb{R}$ called the standard part that rounds off each finite hyperreal $u$ to its nearest real number $u_{0} \in \mathbb{R}$, so that $u_{0}=\operatorname{st}(u)$ and $u \approx u_{0}$.

\footnotetext{
${ }^{14}$ Leibniz actually used a symbol that looks more like $\sqcap$ (see Katz-Sherry 2013) but the latter is commonly used to denote a product.
} 
Proof. The result holds generally for an arbitrary ordered field extension $F$ of $\mathbb{R}$. Indeed, if $x \in F$ is finite, then $x$ induces a Dedekind cut on the subfield $\mathbb{Q} \subseteq \mathbb{R} \subseteq F$ via the total order of $F$. The real number corresponding to the Dedekind cut is then infinitely close to $x$.

Example 1.9. A number $E$ is infinitesimal if and only if $\operatorname{st}(E)=0$.

1.9. Transcription of Fermat's argument. Fermat illustrates his method by solving the following problem: subdivide a given segment into two subsegments so as to maximize the area of the rectangle formed by the two subsegments [Fermat 1891, p. 134].

Fermat denotes the length of the original segment by $B$ and the length of a first subsegment by $A$, so that the second subsegment is of length $B-A$. The expression to be maximized is

$$
B A-A^{2} \text {, }
$$

where we used the Cartesian notation for arithmetic operations for greater readability. Fermat now replaces the first subsegment by $A+E$ so that the second one becomes $B-A-E$, with product $B A-A^{2}+B E-$ $2 A E-E^{2}$. Fermat compares the latter to the previous product $B A-A^{2}$ and suppresses common terms.

Remark 1.10. At the next stage, Fermat gathers together terms with of same sign, namely he groups the positive terms together and the negative terms together.

This enables him to form the adequality

$$
B E \text { adaequabitur } 2 A E+E^{2} \text {, }
$$

Dividing out by $E$, Fermat obtains the adequality

$$
B \text { adaequabitur } 2 A+E \text {. }
$$

Suppressing the remaining term E, Fermat obtains an equality

$$
B \text { aequabitur } 2 A \text {. }
$$

Fermat concludes that to solve the problem one needs to take (for $A$ ) half of $B$.

Remark 1.11. This is one of many instances when the characteristic pair "adequality, equality" (in that order) occurs in Fermat's description of his method.

Let us transcribe Fermat's argument in the language developed in Section 1.8 by rewriting his sequence of operations in modern notation as follows:

$$
B E \sqcap 2 A E+E^{2},
$$




$$
\begin{gathered}
B \sqcap 2 A+E, \\
B=2 A .
\end{gathered}
$$

In terms of modern proxies, the passage from relation (1.4) to relation (1.5) is justified by Theorem 1.7. The passage from relation (1.5) to equality (1.6) is justified by applying the standard part function of Theorem 1.8 using the fact that $\operatorname{st}(E)=0$.

Remark 1.12. The passage from equation (1.4) to equation (1.5) enabled by Theorem 1.7 is only possible if one works with a multiplicatively invariant relation $\square$ as we did, rather than with the relation of infinite proximity $\approx$ (see Section 1.8 ).

1.10. Text sent to Descartes. At the outset of a text on Fermat's method sent to Descartes toward the end of 1637 and received by the latter at the beginning of 1638, Fermat starts with a term (expression) containing an unknown $A .15$ Fermat goes on to substitute $A+E$ in place of $A$, and writes:

Adaequentur, ut loquitur Diophantus, duo homogenea maximae aut minimae aequalia [Fermat 1891, p. 133]

(see Section 1.11 for details and translation). Following the steps outlined in Section 1.3 (and in more detail in Section 1.9), Fermat concludes:

The solution of this last equality will give the value of $A$, which known, the maximum or minimum will become known by repeating the traces of the foregoing resolution. Mahoney 1994, p. 162]

It is only at this stage in the algorithm that the unknown $A$ becomes a constant $A$, namely the desired point of maximum 16

1.11. Original Latin. The original Latin of the passage on Diophantus cited in Section 1.10 reads as follows:

\footnotetext{
${ }^{15}$ In $A d$ eamdem methodum (item III in Fermat 1891]), Fermat refers to $A$ as incognitam (unknown) Fermat 1891, p. 140]. A text starting with the words "Je veux par ma méthode" is a translation (of the above) dating from 1638 in old French first published in Fermat 1922. This text refers to $A$ as an inconnue Fermat 1922, p. 74, line 7] and similarly at [Fermat 1922, p. 80, line 4]. Fermat similarly describes $A$ as inconnue in a 22 october 1638 letter to Mersenne Fermat 1894, p. 170, $175]$.

${ }^{16}$ Thus Breger's claim to the effect that "in the first text on the method sent to Descartes, adaequare means equality" Breger 2013, p. 21] has no basis; see Section 2.1.
} 
Adaequentur, ut loquitur Diophantus, duo homogenea maximae aut minimae aequalia et, demptis communibus (quo peracto, homogenea omnia ex parte alterutra ab $E$ vel ipsius gradibus afficiuntur), etc. [Fermat 1891, p. 133].

Mahoney translates this passage as follows:

Adequate 17 as Diophantus says, the two homogeneous expressions equal to the maximum or minimum and, having removed common terms (which done, all homogeneous quantities on either side will contain $E$ or degrees of it), etc." [Mahoney 1994, p. 162]

Note that Fermat speaks of two homogeneous expressions equal to the (i.e., representing the unknown) maximum. He does not speak of two homogeneous expressions equal to each other 18

1.12. Fermat's Sur la même méthode. Fermat's Latin text Ad eamdem methodum (item VI in [Fermat 1891]) starts at [Fermat 1891, p. 158]. We will use Tannery's translation Sur la même méthode for the reader's convenience. Here we find:

Nous considérons en fait dans le plan d'une courbe quelconque deux droites données de position, dont on peut appeler l'une diamètre, l'autre ordonnée. Nous supposons la tangente déjà trouvée en un point donné sur la courbe, et nous considérons par adégalité la propriété spécifique de la courbe, non plus sur la courbe même, mais sur la tangente à trouver. En éliminant, suivant notre théorie des maxima et minima, les termes qui doivent l'être, nous arrivons à une égalité qui détermine le point de rencontre de la tangente avec le diamètre, par suite la tangente elle-même 19 [Fermat 1896, p. 141]

\footnotetext{
${ }^{17}$ Mahoney is using adequate as an English verb; cf. note 5 .

${ }^{18}$ This is contrary to Breger's claim at Breger 2013, p. 28, line 3]. Breger reproduces only a misleadingly truncated fragment of Fermat's Latin phrase, in footnote 50 there to support his dubious claim. Breger's fragment is "duo homogenea maximae aut minimae aequalia." However, Breger's fragment does not make sense grammatically, because the words "maximae/minimae" only make sense in Fermat's full phrase as Datives construed with "aequalia", namely "two homogeneous terms equal to the maximum or the minimum". The two homogeneous expressions are not equated but rather adequated by Fermat. In the 1638 text mentioned in note 15 Fermat writes (in old French) explicitly: "comme s'ils estoient esgaux, bien qu'en effect ils ne le soient pas" Fermat 1922, p. 74, lines 15-16].

${ }^{19}$ Latin original: "Consideramus nempe in plano cujuslibet curvae rectas duas positione datas, quarum altera diameter, si libeat, altera applicata nuncupetur.
} 
(emphasis on diamètre and ordonnée in the 1896 source; emphasis on adégalité and égalité added)

Here similarly, adequality refers to unknowns, whereas equality refers to the value of the constant found. Thus Fermat is expressing distinct ideas when he uses the words adaequalitas and aequalitas. The characteristic pair "adequality, equality" occurs here as elsewhere in that specific order; see Remark 1.11 on page 12.

[Note added after publication: After the article was published online (see http://dx.doi.org/10.1007/s10699-017-9542-y) at Foundations of Science, we came across an important piece of evidence concerning Fermat's Toulouse friend Lalouvère, jesuit, mathematician, and censor. Indeed, Antonella Romano writes: "Un premier constat regarde les jésuites confrontés à la censure: sur tous les cas du Fondo Gesuitico qui concernent la France, deux professeurs seulement appartiennent à la liste établie dans le cadre de cet ouvrage, B. Labarthe et V. Léotaud. Si d'autres mathématiciens y apparaissent, c'est tout aussi exceptionnellement, et au titre de censeur, comme Antoine Lalouvère ${ }^{114}$ " Romano 1999, p. 512]. Footnote 114 there reads: "C'est lui qui porte un jugement négatif sur l'ouvrage de B. Labarthe." Thus, Lalouvère in his capacity as a censor sank at least one book, namely that by his fellow jesuit Labarthe.]

\section{ReduCTIVE READINGS}

Reductive tendencies in modern historiography of mathematics were analyzed in Katz-Katz 2012]; see also Section 2.7. Some Fermat scholars have argued recently that adequality meant equality or setting equal, that Fermat's procedure was purely algebraic, and that no idea of approximation was involved.

2.1. Reductive readings of adequality: Breger. Breger's reading along these lines was critically analyzed in [Katz et al. 2013]. That such scholars are in a distinct minority emerges from the following comment of Breger's:

Although there are considerable differences between various interpretations, there seems to be a common dogma, to which all interpreters, as far as I know, agree, namely:

Deinde, jam inventam tangentem supponentes ad datum in curva punctum, proprietatem specificam curvae, non in curva amplius, sed in invenienda tangente, per adaequalitatem consideramus et, elisis (quae monet doctrina de maxima et minima) homogeneis, fit demum aequalitas quae punctum concursûs tangentis cum diametro determinat, ideoque ipsam tangentem" [Fermat 1891, p. 159]. 
Fermat uses the word 'adaequare' in the sense of 'to be approximately equal' or 'to be pseudo-equal' or 'to be counterfactually equal' Breger 1994, p. 194]. (emphasis in the original)

Why is it that "all interpreters," as reported by Breger, agree that a relation more general than equality and exploiting in some way inequality is involved in Fermat's method? Possibly it is because Fermat himself said so in a letter to Mersenne:

Cette comparaison par adégalité produit deux termes inégaux qui enfin produisent l'égalité (selon ma méthode), qui nous donne la solution de la question [Fermat 1638, p. 137] (emphasis on adégalité in the original; emphasis on inégaux added)

(see Section 2.2 for details). Similar remarks apply to Fermat's later missive to Descartes mentioning adéquation and inequalities involved; see [Fermat 1894, p. 155]. Meanwhile, Breger claims that

two homogeneous quantities that are each equal to the maximum or minimum are obviously equal to each other and not only approximately equal Breger 2013, p. 21, note 6$]$.

A similar claim had already appeared in [Breger 1994, p. 195]. Breger's inference is based on assuming that the symbol $A$ appearing in Fermat's argument (see Section 1.10) is a constant rather than an unknown throughout the argument, but $A$ is clearly an unknown at the outset of the argument and only becomes a constant at the end, as analyzed in Sections 1.10 and 1.12. Thus Breger's inference is based on a confusion of unknowns and constants.

2.2. Fermat's letter; enfin. For the sake of completeness we reproduce the full passage from Fermat's letter to Mersenne cited in Section 2.1, which uses the term adégalité twice:

6. Outre le papier envoyé à $\mathrm{R}$ (oberval) et $\mathrm{P}$ (ascal), pour suppléer à ce qu'il y a de trop concis, il faut que M. Descartes sache, qu'après avoir tiré la parallèle qui concourt avec la tangente et avec l'axe ou diamètre des lignes courbes, je lui donne premièrement le nom qu'elle doit avoir comme ayant un de ses points dans la tangente, ce qui se fait par la règle des proportions qui se tire des deux triangles semblables. Après avoir donné le nom, tant à notre parallèle qu'à tous les autres termes 
de la question, tout de même qu'en la parabole, je considère derechef cette parallèle, comme si le point qu'elle a dans la tangente étoit en effet en la ligne courbe, et suivant la propriété spécifique de la ligne courbe, je compare cette parallèle par adégalité avec l'autre parallèle tirée du point donné à l'axe ou diamètre de la ligne courbe. Cette comparaison par adégalité produit deux termes inégaux qui enfin produisent l'égalité (selon ma méthode), qui nous donne la solution de la question. [Fermat 1638, p. 137] (emphasis on enfin added)

The adverb enfin indicates that something novel occurs at the end of the argument that hasn't been the case earlier: namely, equality. In the same letter Fermat makes (only a half-)joking reference to "ma petite guerre contre M. Descartes" (ibid., item 5); one has to assume that under the circumstances Fermat would have endeavored to provide his best available explanation of the method.

2.3. Did Tannery tamper with Fermat's manuscript? A facsimile of a page from Fermat's handwritten manuscript starting with the words Doctrinam tangentium is reproduced between pages xviii and xix in [Fermat 1891]. Here Fermat used the term adaequalitatem once and, two lines later, the term aequalitas once. The characteristic pair "adequality, equality" (see Remark 1.11) occurs numerous times throughout Fermat's writings on the method. Tannery's transcription of Fermat's page appears at [Fermat 1891, pp. 158-159] as part of a text entitled Ad eamdem methodum (item VI in Tannery's edition). The terms in question appear at lines 14 and 16 of page 159 of the transcription. An editorial note at [Fermat 1891, p. 426] deals with Tannery's transcription. The note concerning line 14 states the following: "14 adaequalitatem] aequalitatem Va" [Fermat 1891, p. 426]. Here the abbreviation $V a$ refers to the edition published by Samuel Fermat in 1679 entitled Varia Opera [Fermat 1679, as explained earlier on the same page 426 . The note indicates that Tannery corrected an error that crept into the Varia Opera edition of 1679 (which replaced Fermat's term adaequalitatem by aequalitatem).

We see therefore that Tannery did not attempt to "repair" Fermat's handwritten manuscript. Tannery's transcription, faithful to the original, uses adaequalitatem once at line 14 there, and aequalitas once at 
line 16 Similarly, Tannery's French translation Fermat 1896, p. 141] (reproduced in Section 1.12 above) uses adégalité once and égalité once. Breger writes:

The facsimile (Fermat 1891, after XVIII) gives the impression that the manuscript was not written in a hurry; there are few additions and deletions, and the handwriting is fair. In two passages of the manuscript, Fermat expresses the same idea in nearly identical words, but in [sic] the first time he uses the word adaequalitas, whereas in the second passage the word aequalitas is used (Fermat 1891, 159, 162, 426) [Breger 1994, p. 195].

Breger goes on to claim that

the editors of the Oeuvres deemed it necessary to repair Fermat's supposed confusion by changing the aequalitas into another adaequalitas [but] they nevertheless indicated their change in the critical apparatus (Fermat 1891, 426) Breger 1994, pp. 195-196].

This refers to an edit on page 162 at line 22, from aequalitas to adaequalitas. We will discuss Tannery's edit in more detail in Section 2.4.

2.4. Breger's judgment of Tannery. Breger juxtaposes his judgment of a change in the 1679 edition with his judgment of a change in Tannery's 1891 edition in the following terms:

The editors of (Fermat 1679) present a version which has been changed the other way round: They give twice aequalitas, whereas (Fermat 1891) gives twice adaequalitas. Breger 1994, p. 196].

Breger's tone is even more strident in his 2013 article:

In the only manuscript on the method of maxima, minima and tangents that has been handed down to us in Fermat's own handwriting, aequalitas and adaequalitas are used interchangeably. Unfortunately, the editors of the Fermat edition have interfered with the text to support their own interpretation of the method and they

\footnotetext{
${ }^{20}$ For the sake of completeness we reproduce lines $14,15,16$, and 17 exactly as they appear in [Fermat 1891, p. 159]:

(14) in invenienda tangente, per adaequalitatem consideramus et, elisis

(15) (quae monet doctrina de maxima et minima) homogeneis, fit demum

(16) aequalitas quae punctum concursûs tangentis cum diametro determinat,

(17) ideoque ipsam tangentem.
} 
have declared the text in Fermat's handwriting to be flawed. [Breger 2013, p. 22] (emphasis added)

Breger's claim that Fermat used aequalitas and adaequalitas interchangeably is unsupported by evidence. In fact, Fermat uses them in distinct senses on the page in Fermat's handwriting reproduced between xviii and xix in [Fermat 1891], and accurately transcribed by Tannery on page 159. The term adequality always occurs in tandem with equality with the former denoting a comparison of expressions involving unknowns and the latter, an expression for the constant providing the final answer. Whenever Fermat presents a detailed solution, the characteristic pair "adequality, equality" invariably appears; see Remark 1.11 on page 12 .

Breger's comment at [Breger 1994, p. 196] cited above is equally critical of the changes by the 1679 editors and by the 1891 editors. However, the change made by the 1679 edition at [Fermat 1679, p. 69] was an erroneous replacement of adaequalitatem by aequalitatem, contrary both to the version found in Fermat's handwritten manuscript (see Section 2.3) and to Fermat's description of his method in the text sent to Descartes and appearing at [Fermat 1891, p. 133]; see Section 1.10.

Namely, the edit by the 1679 editors disrupted the characteristic pair "adequality, equality." Such a pair appears in Fermat's detailed presentation of a solution on numerous occasions, including Fermat's usage recorded on page 159 (of the 1891 edition) and Fermat's usage recorded on page 163 (of the 1891 edition) on the cycloid ("curva Domini de Roberval"); see Section 1.3. Therefore the change on page 69 of the 1679 edition constituted an editorial error.

Meanwhile, the change made by Tannery in a passage on page 162, line 22 replacing aequalitas by adaequalitas concerns a stand-alone occurrence of the term (rather than as part of the characteristic pair) in a brief concluding passage, which we reproduce in translation for the reader's convenience:

Enfin, ce qui est le point important, aux arcs de courbes on peut substituer les longueurs correspondantes des tangentes déjà trouves, et arriver à l'adégalité ${ }^{21}$ comme nous l'avons indiqué : on satisfera ainsi facilement à la question 22 [Fermat 1896, p. 143-144]

\footnotetext{
${ }^{21}$ Some of the extant texts have égalité instead.

${ }^{22}$ Latin original: "et demum (quod operae pretium est) portiones tangentium jam inventarum pro portionibus curvae ipsis subjacentis sumantur, et procedat adaequalitas ut supra monuimus: proposito nullo negotio satisfiet." Fermat 1891, p. 162]
} 
Some of the extant texts for this passage have aequalitas and others have adaequalitas, and editor Tannery chose to go with the latter. Tannery appropriately indicated the existence of alternative versions in an editorial note at [Fermat 1891, p. 426] concerning page 162, line 22. Either term would fit here, and the choice does not affect the interpretation of the method.

Breger implies that the 1679 and the 1891 editors were equally guilty of tampering with Fermat's original but Breger's judgment of Tannery's scholarship is biased by Breger's own quest to account for adequality in terms of the double root idea; see Remark 2.3 on page 22.

2.5. Cherry-picked numerology. The numerology of Breger's comment to the effect that "The editors of (Fermat 1679) present a version which has been changed the other way round: They give twice aequalitas, whereas (Fermat 1891) gives twice adaequalitas" Breger 1994, p. 196] is surprising if not to say incomprehensible. Where does the number 2 as in "[t]hey give twice aequalitas, whereas (Fermat 1891) gives twice adaequalitas" come from?

The handwritten manuscript transcribed at Fermat 1891, p. 158167] uses the term adaequalitatem (or adaequetur, adaequalitas, adaequari) no fewer than 10 times 23 Even if one takes off the one occurrence on page 162 that Breger is unhappy about, that still leaves us with nine occurrences of the term in Fermat's handwritten manuscript.

Breger's number 2 seems to be cherry-picked so as to attack Tannery's editing by comparing it to that of the 1679 edition.

2.6. Breger's wrong move. We will now illustrate how a scholar working in an infinitesimal-frei conceptual framework misses important features of Fermat's method. Let us consider Breger's transcription of Fermat's argument presented in Section 1.9. Breger writes:

The maximum of $B A-A^{2}$ is to be found. Fermat puts

$$
\begin{gathered}
B A-A^{2}=B(A+E)-(A+E)^{2} \\
2 A E+E^{2}-B E=0 \\
E(2 A+E-B)=0
\end{gathered}
$$

... The procedure consists of three steps: Firstly, two functional expressions for the extreme value are equated; then one divides by $E \ldots$ in the third step $E$ is put equal to zero. [Breger 2013, p. 27] (equation numbers added)

\footnotetext{
${ }^{23}$ More precisely, the term occurs once on each of the pages $159,160,161$, three times on 162, twice on 163 , and twice on 164 .
} 
Breger mentions the steps involving the division by $E$ and setting $E$ equal to zero, but does not include the resulting relations, so we will do it for him, following the style of his formulas (2.1), (2.2), (2.3):

$$
2 A+E-B=0
$$

and then

$$
2 A-B=0 .
$$

What is striking about Breger's paraphrase is its insensitivity to the details of Fermat's mathematical presentation. Breger's relation (2.1) is true to Fermat but already Breger's next relation (2.2) betrays Fermat.

Remark 2.1. As is evident from our summary in Section 1.9, Fermat never moved the terms to the left-hand side as Breger did. In fact, Fermat wrote: "aequentur sane ...negata affirmatis" Fermat 1891, p. 134] which Mahoney translates as "equate... the negative terms to the positive" [Mahoney 1994, p. 162]; see Remark 1.10, Breger's wrong move makes Fermat's procedures appear unclear or even confused, as we now show.

The transition from Breger's relation (2.2) to relation (2.3) is an unproblematic algebraic transformation using the distributive law. However, Breger's next step is problematic and in fact untenable.

Remark 2.2. The transition from Breger's relation (2.3) to Breger's relation (2.4) can be justified neither in terms of the relation $\approx$ nor in terms of the relation $\square$; see Remark 1.12. Nor did Fermat use 0 appearing on Breger's right-hand side.

If one wishes to interpret relation (2.4) as true equality as Breger does, the passage from (2.4) to (2.5) becomes incomprehensible. More precisely, it forces $E=0$ and invalidates any possible passage from (2.3) to (2.4).

Breger is "shocked" at Breger 2013, pp. 25-26] by Hérigone's Cursus mathematicus which if interpreted literally appears to present a version of Fermat's method where one patently divides by zero to obtain the final result. Yet Breger's own flawed paraphrase at [Breger 2013, p. 27] similarly relies on $E$ being first nonzero and then zero.

Breger declares that "for the sake of clarity a $\ldots=0$ is occasionally used, although Fermat himself avoids using it" Breger 2013, p. 29] but what Breger introduced by tampering with Fermat's presentation is not clarity but rather confusion.

In 1642, Hérigone presented the same example while retaining Fermat's balanced presentation:

$$
2 a e+e^{2} \quad 2 \mid 2 \quad e b
$$


followed by

$$
2 a+e \quad 2 \mid 2 \quad b
$$

and finally

$$
2 a \quad 2 \mid 2 \quad b
$$

(here $2 \mid 2$ denotes an equality sign) as found in [Hérigone 1642, p. 60]. To his credit, Barner 2011, p. 18] treats the same example without distorting Fermat's method the way Breger does by moving the terms to the left-hand side.

Remark 2.3. Why did Breger move the terms to the left-hand side so as to obtain the formula $2 A E+E^{2}-B E=0$ as in (2.2), whereas neither Fermat nor his popularizer Hérigone did? The polynomial $2 A E+$ $E^{2}-B E$ has a double root when $A=B / 2$. Breger seeks a uniform interpretation of Fermat's method in terms of the double root idea. But this is not Fermat's way. The double root idea is present in Fermat's work but the method of adequality is more general and some of its applications resist Breger's reductive paraphrase. Imagine what Unguru might think of such a left-handed move.

2.7. Triumvirate bias. Carl Boyer referred to Cantor, Dedekind and Weierstrass (CDW) as "the great triumvirate" in [Boyer 1949]. A hagiographic attitude toward CDW tends to go hand-in-hand with a distrust of mathematics that CDW were unable to formalize, such as infinitesimals.

Thus, volume 4 of Fermat's collected works contains the following dismissive comments by A. Aubry concerning Kepler and Cavalieri:

[Fermat] semble admettre ainsi, comme Kepler et Cavalieri, l'existence réelle des infiniment petits, et ce principe que deux quantités ne différant que d'un infiniment petit sont égales; tandis qu'au contraire Descartes se fonde sur la théorie des racines égales, c'est-à-dire, au fond, sur celle des limites"24 [Fermat 1912, p. 225].

Aubry clearly has little confidence in "really existing infinitesimals" or for that matter in a relation of generalized equality between quantities differing by an infinitesimal.

Scholars trained in the traditional Weierstrassian framework based upon the real continuum tend to privilege such a framework over other modern frameworks even when the latter are procedurally closer to the pioneering epoch of analysis. Breger frequently mentions the following two points in close proximity to each other:

\footnotetext{
${ }^{24}$ From an editorial comment on page 145 in the same volume it emerges that Aubry developed his remarks (in Note XXV) especially for the 1912 volume.
} 
(1) the concept of approximate equality, and

(2) the issue of Fermat being unclear, confused, or contradictory.

Such juxtaposition suggests the existence of an implied connection between the two points in Breger's mind. Thus, he writes:

2.7.1. "The commonly accepted interpretations of Fermat's method of extreme values tell us that this is a curious method, based on an approximate equality and burdened with several contradictions within Fermat's writings." Breger 1994, p. 139] (emphasis added)

2.7.2. "Although there are considerable differences between various interpretations, there seems to be a common dogma, to which all interpreters, as far as I know, agree, namely: Fermat uses the word 'adaequare' in the sense of 'to be approximately equal' .. Usually, the explicit or tacit assumption is made that Fermat himself was somewhat confused." Breger 1994, p. 194] (emphasis added)

2.7.3. "In two passages of the manuscript, Fermat expresses the same idea in nearly identical words, but in [sic] the first time he uses the word adaequalitas, whereas in the second passage the word aequalitas is used (Fermat 1891, 159, 162, 426). If the dogma of the usual interpretation is assumed, then this is another example of Fermat's supposed confusion." [Breger 1994, p. 195] (emphasis added)

2.7.4. "Looking at these oddities, we finally arrive at an alternative and at a warning. The alternative is: Either Fermat was pretty confused - far more confused than a mathematician presenting one of his central ideas is expected to be - or something is fundamentally wrong with our understanding of Fermat's method of extreme values." [Breger 1994, p. 196] (emphasis added)

Breger's tone becomes progressively more strident:

2.7.5. "There is no approximate equality involved in Fermat's insight and in his application of the Diophantus passage. Thus I would like to conclude that these words were written by someone who did not really understand the meaning of Fermat's reference to Diophantus. ... It seems hard to believe that Fermat could have been so confused as to write this rubbish." Breger 1994, p. 210] (emphasis added)

2.7.6. "The text's contradictoriness cannot be remedied by using words such as 'approxiately equal, conterfactually equal, pseudoequal, limit process, infinite approximation, infinitesimal' in their interpretation. If one finds it hard to believe that Fermat had repeatedly got caught up in contradictions, etc." Breger 2013, p. 20] (emphasis added) 
The following passage is particularly revealing of Breger's assumption that an approximate equality cannot be part of a proper proof:

2.7.7. "[Fermat] knew that an approximate equation was different from a proven convergence (even though he did not yet have the word convergence), and it would be most strange if he had not distinguished the one from the other." Breger 2013, p. 23] (emphasis added)

These passages juxtaposing the idea of approximation and the idea of confusion reveal Breger's manifest belief that viewing Fermat as using any version of approximate equality is inevitably tied in with viewing Fermat as using arguments that were only approximately correct and thus vague or confused.

Scholars trained in the Weierstrassian school tend to assume that any relation of approximate equality necessarily constitutes a vague or even confused concept from a strictly mathematical viewpoint. This type of bias results from the fact that no such relation is available in the context of the real continuum. However, such relations are indeed available in infinitesimal-enriched frameworks; see Section 1.9.

2.8. Breger's equivocation. Breger's interpretation is based on an equivocation on the meaning of Fermat's term. Breger seeks to assign two distinct meanings to the term adequality:

(1) simple coincidence and/or equivalence;

(2) "setting equal" in the sense elaborated by Breger in his paper.

Breger's claim that Fermat used the terms equality and adequality interchangeably is only plausible if based on the sense (11). However, Breger himself explains the term adequality in the sense (2) relying on a theorem he states at [Breger 2013, p. 29] exploiting expressions like $(f(x, g(x))$ and bearing a close resemblance to an implicit function theorem; Barner explicitly admits using such a 19th century result in [Barner 2011, p. 17].

2.9. Fermat versus Breger. We bring the following comparison to our readers' attention. 
Fermat to Mersenne: 'Cette Breger: 'Fermat's method is comparaison par adégalité pro- not to be located in the reduit deux termes inégaux qui gion of approximations... It has enfin produisent l'égalité (selon nothing to do with an approxma méthode), qui nous donne imate equality, and thus lacks la solution de la question.' any basis for assumptions about [Fermat 1638, p. 137] limit processes or infinitesimals.' Breger 2013, p.40]

2.10. A self-inflicted textual difficulty. In his text Ad eamdem methodum (item III in [Fermat 1891]), Fermat speaks of comparison by adequality:

Comparanda sunt ergo homogenea notata signo +cum iis quae notantur signo -, et iterare comparationem [adaequalitatem] oportet inter $B$ in $E q$. $+B$ in $A$ in $E$ bis ex una parte, et $A$ in $E q$. ter $+A q$. in $E$ ter $+E c$. ex altera. [Fermat 1891, pp. 140-141] (emphasis added)

Note that the brackets around adaequalitatem are Tannery's (they are not to be found in Samuel Fermat's edition [Fermat 1679, p. 66]). In footnote 1 on page 141, Tannery notes that the text may not be authentic since Fermat should have written only one of the two words, which according to Tannery Fermat used as synonyms:

Le texte véritable est douteux: Fermat n'a dû écrire que l'un des deux mots, comparationem ou adaequalitatem, qu'il employait comme synonymes; l'autre serait une glose du copiste ou du possesseur de l'original. Même remarque pour comparatio et adaequalitas, quatre lignes plus bas. [Fermat 1891, p. 141, note 1] (emphasis in the original)

But in de Waard's volume we find Fermat's French translation of this text, where Fermat again speaks of comparison by adequality:

Il faut donc comparer les homogènes qui sont marquez du signe + avec ceux qui sont marquez du signe - , et faire derechef comparaison adaequalitatem entre $B$ in $E q$. $+B$ in $A$ in $E$ bis d'un costé, et $A$ in $E q$. ter + $A q$. in $E$ ter $+E c$. de l'autre. [Fermat 1922, p. 75] (emphasis in the original) 
This time it is editor de Waard's turn to add a footnote 1 concerning alleged textual difficulties, without however adding brackets around adaequalitatem.

In fact there is no difficulty here since Fermat is using comparison in a generic sense of the word, whereas he is using adequality as the specific technical term exploited in his method, as he writes:

... et i'ay appelé en mon escrit latin cette sorte de comparaison adeaqualitatem ... [Fermat 1922, p. 74]

Moreover, in his remarks about Diophantus in [Fermat 1891, p. 140] [Fermat 1922, p. 74], Fermat also uses both words but here Tannery and, following him, de Waard do not protest.

It seems that recognizing the possibility that Fermat fully intended to use both words (comparison by adequality) involves imagining a mathematically precise notion of generalized equality different from the generic sense of comparison, an idea apparently not easy in a world of post-Weierstrassian historiography.

2.11. Reductive readings of adequality: Felgner. Ulrich Felgner for his part focuses on examples reducible to a polynomial which is positive in a neighborhood of a zero at $h=0$, and seeks to account for all these examples based on his interpretation of $\pi \alpha \rho \iota \sigma o ́ \tau \eta \varsigma$ in Felgner 2016. However, he is unable to account for Fermat's treatment of transcendental curves like the cycloid, a difficulty one would expect in light of Weil's thesis; see Section 1.4.

2.12. Reductive readings of adequality: Barner. In an odd twist of Fermat scholarship, Klaus Barner appears to hold that he understood Fermat's method better than... Fermat himself. Barner claims that Fermat's attempt to explain his method of calculating the tangent at a given point of a curve is somewhat confusing (!), that Fermat actually calculates with a secant line which converges to the tangent as the limit line, and that Fermat's problem is that he calculates with secants without being aware of that; cf. [Barner 2011, pp. 32-36].

The problem with Barner's approach is not merely that, as he seems to acknowledge, there is no evidence for his secant hypothesis in Fermat's texts, but also that the secant approach is known as Jean Beaugrand's rather than Fermat's, as analyzed in Strømholm 1968, pp. 6465] and noted in Katz et al. 2013. In fact, Barner's secant reading is not new. Cifoletti writes:

[Zeuthen] fait référence à une sécante, (qui approximerait la tangente). Cela est surprenant, puisqu'il n'y a aucun texte de Fermat sur lequel appuyer cette interpretation. 
Bien entendu, la version de Beaugrand suit cette approche [Cifoletti 1990, p. 47].

The Zeuthen-Barner reading of Fermat's method has not been accepted by modern Fermat scholars.

\section{Historical Setting}

A review of the historical setting at the time of Fermat's activity in mathematics will necessarily involve his professional activities as member of the Parliament of Toulouse.

3.1. Salient historical points. The 11 relevant points are as follows.

3.1.1. Parliament. The modern connotations of the term Parliament should not mislead one into thinking about 17th-century Toulouse in terms of modern political concepts. In the 17th century the doctrine of the separation of powers was not even conceived, let alone implemented, in the Western world. The Parliament of Toulouse was the local judicial, legislative, and executive power rolled into one, and subordinate only to the king of France.

3.1.2. Venality. Fermat, like just about everybody else who served in the Parliament, had to pay a hefty fee 25 for the privilege.

3.1.3. Counterreformation. This was the period of counter-reformation, when the interdenominational strife was at its height. Fermat was catholic but his parents had some protestant sympathies 26 Fermat's "mixed" background was to influence the trajectory of his professional activities as well.

\footnotetext{
${ }^{25}$ Of 43500 livres [Mahoney 1994, p. 16] in Fermat's case. At the time all public functions were sold under certain conditions [Mousnier 1971.

${ }^{26}$ Fermat's probable mother, Claire née de Long, came from a Huguenot family from Montauban, a Huguenot stronghold Gairin 2001. His wife (and distant cousin) Louyse was also a de Long (Mouranche 2017 prefers the spelling "Louise" while Codicille au testament de Pierre de Fermat uses the spelling "Louyse" Chabbert 1967, p. 347]). In addition, Fermat had close protestant friends in the Chambre d'Édit at Castres, namely Pierre Saporta and Jacques de Ranchin Chabbert 1967. The claim that Fermat "was baptized (and most probably born) on 20 August 1601 to Dominique Fermat ... and his wife Claire, née de Long" Mahoney 1994 p. 15] is incorrect, since we know that in 1603 Dominique was still married to Françoise Cazeneuve [Spiesser 2008, p. 172]. Claire de Long's grandfather Jean de l'Hospital was a Huguenot expelled from the Parliament for religious reasons; see Section 5.1 .
} 
3.1.4. Castres. Whereas Fermat was based at Toulouse, he paid frequent visits to the city of Castres starting in 1638 [Chabbert 1967, p. 340] with protestant leanings, in his function as member of the Chambre de l'Édit27 of the Parliament of Toulouse. This was done in his capacity as negotiator of catholic/protestant tensions; see Section 5 .

3.1.5. Eucharist and atomism. One of the stickiest points of the catholic/protestant disagreement concerns the doctrine of the eucharist (see Section 4.8). What is relevant as far as Fermat's mathematics is concerned is that the theory of atomism and kindred doctrines were viewed by some catholic theologians as a threat to their interpretation of the doctrine of the eucharist; see Section 4.10 on Trent 13.2.

3.1.6. Atomism and indivisibles. Perhaps through careless choice of wording by Cavalieri in his correspondence with Galileo and others, atomism was closely associated with mathematical indivisibles 28 Cavalieri belonged to the order of the jesuats, which was an older order than the jesuit order and something of a rival. Jesuit Guldin attacked Cavalieri both for allegedly plagiarizing Kepler and for an alleged fundamental incoherence of Cavalieri's technique exploiting indivisibles.

3.1.7. Indivisibles and infinitesimals. Modern scholars distinguish carefully between indivisibles and infinitesimals but in the 17th century the situation was less clearcut. Similarly, there was no clear-cut distinction at the time between physical indivisibles and mathematical indivisibles. The distinction commonly made today follows Koyré 1954 (among others). The distinction is that indivisibles are codimension-one entities 29 whereas infinitesimals are of the same dimension as the entity they make up (curve, planar region, etc). The term infinitesimal was coined by either Mercator or Leibniz in the 1670s; see Leibniz 1699, p. 63]. Similarly, there was no clear-cut distinction at the time between physical indivisibles and mathematical indivisibles. Festa observes:

L'atomisme était mêlé à ces discussions car les jésuites, ceux du Collegio Romano surtout, ne faisaient pas grande

\footnotetext{
${ }^{27}$ This refers to the Edit de Nantes (1598) or the Edict of Nantes, where a compromise was reached between catholics and protestants that held until its abolition in 1685 by the l'Etat, c'est Moi (The State, it is Myself) king who apparently found no room within either his catholic self or his State for protestantism.

${ }^{28}$ Lalouvère specifically complained about this choice of terminology, as noted in Descotes 2015, p. 269].

${ }^{29}$ This means that the dimension of the entity is one less than the dimension of the ambient figure.
} 
distinction entre 'milieux géométriques' et 'milieux physiques' lorsqu'il s'agissait de manifester leur opposition à la notion de 'discontinuité' [Festa 1991, p. 103].

There was apparently a close connection, in the eyes of the catholic clergy, among atoms, indivisibles, and the infinitely small.

3.1.8. Anti-infinitesimal bans. Festa documents a series of bans issued by the jesuit establishment against indivisibles, including one in 1632, the year Galileo received a summons to stand trial over heliocentrism; see [Festa 1990 and [Festa 1992, p. 207]. Only a few years earlier (around 1629) Fermat developed the technique of adequality at Bordeaux.

3.1.9. Degli Angeli. Cavalieri's student (or student's student via Torricelli) Stefano degli Angeli was also a member of the order of the jesuats. He published many books on indivisibles, and also published several spirited, and sometimes strongly worded, defenses of indivisibles against attacks by jesuit scholars like Paul Guldin, Mario Bettini, and André Tacquet [Redondi 1987, p. 291]. In 1668 the order of the jesuats was banned by papal brief, providing essentially no explanation. Degli Angeli lived many years afterwards and published many additional books, but he never published another word on indivisibles.

3.1.10. Gregory. James Gregory was degli Angeli's student during his stay in Padua from 1664 until 1668. Gregory's books were suppressed in Venice around 1668 or 1669; see Section 4.7.

3.1.11. Lalouvère. Fermat was in contact with the jesuit Antoine Lalouvère at Toulouse who was interested in mathematics (though the latter was absent from Toulouse between 1632 and 1640). Starting in 1658 Fermat helped Lalouvère with part of the latter's submission to the contest of the roulette (to determine the area of regions defined in terms of the cycloid curve) launched anonymously by Pascal (and eventually won by Pascal). Via Lalouvère and other channels, Fermat would have been aware of the jesuits' position on indivisibles and related doctrines.

3.2. The 17th century scientific context. Most scholars acknowledge that infinitesimal analysis was a natural outgrowth of the techniques of indivisibles as developed by Galileo's student Cavalieri, and in fact Galileo's own work may be closer to the infinitesimal techniques of their contemporary Kepler.

Earlier authors used other terms. Thus, Kepler referred to a point of the circumference of the circle as a basis quantulacunque; to a straight line, as an areola; a rotating axis moved minimum about itself, etc. 
Yet he meant what we would call today the infinitely small. Galileo spoke of non-quanta Bascelli 2014a, Bascelli 2014b]. Other authors referred either to infinite parva or various translations thereof of type infinitely small, infiniment petit, etc.

Ingegno discusses 17th century atomism, vacuum, and the related theological difficulties in the following terms:

Le vide renvoyait aux positions atomistiques qui, dans l'école galiléenne, s'appuyaient sur l'enseignement du maître. Il s'agit en particulier de l'enseignement dispensé par Galilée déjà âgé. . . Les discussions européennes sur le vide ne pouvaient qu'accentuer les critiques antiaristotéliciennes 30 et les difficultés théologiques qui apporteront bientôt des arguments solides aux adversaires des nouvelles orientations" Ingegno 2002, p. 313-314].

The theological difficulties involved included the eucharist:

nous ne savons pas grand-chose de la défense de l'atomisme tentée par Rossetti pour surmonter les difficultés que cette doctrine soulevait pour une interprétation traditionnelle du Mystère de l'Eucharistie. (ibid.)

Indivisibles similarly were perceived as a theological threat and opposed on doctrinal grounds in the 17th century Feingold 2003. The opposition was spearheaded by clerics and more specifically by the jesuits. Tracts opposing indivisibles were composed by jesuits Paul Guldin, Mario Bettini, and André Tacquet [Redondi 1987, p. 291]. P. Mancosu writes:

Guldin is taking Cavalieri to be composing the continuum out of indivisibles, a position rejected by the Aristotelian orthodoxy as having atomistic implications. ... Against Cavalieri's proposition that "all the lines" and "all the planes" are magnitudes - they admit of ratios - Guldin argues that "all the lines ... of both figures

\footnotetext{
${ }^{30}$ Being contrary to Aristotle was viewed as a serious offense by the catholic hierarchy. Thus, part of jesuit Biancani's book was censored on the grounds that "The addition to Father Biancani's book about bodies moving in water should not be published since it is an attack on Aristotle and not an explanation of him (as the title indicates). Neither the conclusion nor the arguments to prove it are due to the author, but to Galileo. And it is enough that they can be read in Galileo's writings. It does not seem to be either proper or useful for the books of our members to contain the ideas of Galileo, especially when they are contrary to Aristotle." (quoted in De Ceglia 2003, p. 162])
} 
are infinite; but an infinite has no proportion or ratio to another infinite." [Mancosu 1996, p. 54]

Tacquet for his part declared that the idea of quantity composed of indivisibles makes war upon geometry to such an extent, that if it is not to destroy it, it must itself be destroyed; see [Festa 1992, p. 205], [Alexander 2014, p. 119].

\section{Social, Religious, AND Military 17Th CENTURY BACKGROUND}

In this section we seek to present the social, religious, and military background of the first half of the 17th century Italy and France. This background helps understand the professional and religious constraints Fermat was operating under.

4.1. Bans on indivisibles. In 1632 (the year Galileo received summons to stand trial over heliocentrism) the Society's Revisors General led by Jakob Bidermann banned teaching indivisibles in their colleges [Festa 1990], [Festa 1992, p. 198, 207]. The proposition and the ban read as follows:

Continuum permanens potest constare ex solis indivisibilibus physicis, seu corpusculis atomis, habentibus partes mathematicas, in ipsis designabiles, etiamsi realiter dicta corpuscula inter se distinguantur. Tempus quoque ex instantibus, \& qualitates intensae, ex solis gradis indivisibilibus constant.

Hanc propositionem arbitramur, non modo repugnare communi Aristotelis doctrina, sed etiam secundum se esse improbabilem, etc. [Festa 1992, p. 207]

This can be translated as follows:

A permanent continuum may consist of physical indivisibles, or minimal particles, alone, which have mathematical parts that can be designated by themselves: even though in reality the said particles are distinct from each other. Time, too, [consists] of instants, and intense qualities 31 consist of indivisible grades alone.

\footnotetext{
${ }^{31}$ This refers to a scholastic dispute as to whether qualities that differ in intensity differ in number: is there a numerical difference between the anger of a person who is very angry and one who is only slightly so?
} 
We consider that this proposition not only stands in opposition to the common doctrine of Aristotle 32 but is also improbable in itself, etc.

Referring to this ban, Feingold notes:

Six months later, General Vitelleschi formulated his strong opposition to mathematical atomism in a letter he dispatched to Ignace Cappon in Dole: "As regards the opinion on quantity made up of indivisibles, I have already written to the Provinces many times that it is in no way approved by me and up to now I have allowed nobody to propose it or defend it." Feingold 2003, pp. 2829] (emphasis added)

To dispel any remaining doubts, Vitelleschi put his foot down:

"If it has ever been explained or defended, it was done without my knowledge. Rather, I demonstrated clearly to Cardinal Giovanni de Lugo himself that I did not wish our members to treat or disseminate that opinion." (ibid.)

Indivisibles were placed on the Society's list of permanently banned doctrines in 1651 [Hellyer 1996]. One might wonder why a society dedicated to furthering the pope's cause on the battlefield of ideas would be interested in mathematics in the first place, whether Euclidean or otherwise. As Amir Alexander colorfully puts it, "Ignatius of Loyola, founding father of the Society ... was not enamored of mathematics" Alexander 2014, p. 52]. The answer, as argued by Alexander, is Clavius. It was C. Clavius (1538-1612) who engineered the acceptance of the new calendar by pope Gregory 13 and the catholic clergy. The development of the calendar patently required a great deal of mathematical competence. Riding the wave of that success, Clavius was able to convince the jesuit hierarchy to incorporate Euclid into their basic curriculum.

4.2. "Vide intégral". The holy war led by jesuits Bettini, Bidermann, Grassi, Guldin, Inchofer, Pallavicino, Tacquet, Vitelleschi, and others to purge Italy of atoms and indivisibles bore fruit, and by 1700 Italy was a mathematical desert:

en 1700, c'est le vide intégral en ce qui concerne la pratique des mathématiques nouvelles en Italie... Robinet 1991, p. 183]

\footnotetext{
${ }^{32}$ This passage of the ban alludes to the Aristotelian doctrine of hylomorphism; see note 30.
} 
It took a sustained multi-year campaign orchestrated by Leibniz and mobilizing everybody from Varignon in Paris, Johann Bernoulli in Basel, the Hanover ambassador Bothmer, to Army Chief Schulenburg in order to install a leibnizian oltramontani, Jakob Hermann and subsequently Nicolas Bernoulli, in the mathematics chair at Padua, eventually sparking a mathematical renaissance in Italy:

L'enseignement d'Hermann à la chaire de mathématiques de Padoue est reconstituable grâce aux apports de plusieurs fonds ... Les annonces des Rotuli de l'université concernent les intitulés des cours annuels, qui changent totalement de ce à quoi on était habitué et qui ne s'en tiennent plus aux commentaires traditionnels de la géométrie d'Euclide. [Robinet 1991, p. 186]

The jesuits, unfazed, stuck to their Euclidean guns. The effects of antiindivisible bans were still felt in the 18th century, when most jesuit mathematicians adhered to the methods of Euclidean geometry, to the exclusion of the new infinitesimal methods:

... le grand nombre des mathématiciens de [1'Ordre] resta jusqu'à la fin du XVIII ${ }^{e}$ siècle profondément attaché aux méthodes euclidiennes. [Bosmans 1927, p. 77]

4.3. Grassi and Guldin. A critique of Galileo's indivisibles penned by jesuit Orazio Grassi is described by Redondi as follows:

As for light - composed according to Galileo of indivisible atoms, more mathematical than physical - in this case, logical contradictions arise. Such indivisible atoms must be finite or infinite. If they are finite, mathematical difficulties would arise. If they are infinite, one runs into all the paradoxes of the separation to infinity which had already caused Aristotl 33 to discard the atomist theory... [Redondi 1987, p. 196]

This criticism appeared in the first edition of Grassi's book Ratio ponderum librae et simbellae, published in Paris in 1626. According to Redondi, this criticism of Grassi's

exhumed a discounted argument, copied word-for-word from almost any scholastic philosophy textbook... The Jesuit mathematician [Paul] Guldin, great opponent of the geometry of indivisibles, and an excellent Roman friend of [Orazio] Grassi, must have dissuaded him from repeating such obvious objections. Thus the second

33 See note 30 on the role of aristotelianism. 
edition of the Ratio, the Neapolitan edition of 1627 , omitted as superfluous the whole section on indivisibles. Redondi 1987, p. 197]

Grassi and Guldin may have disagreed about the tactics of fighting indivisibles, but they agreed about the need to do so (see also Section 4.10).

4.4. War and pope. There is an aspect of political history that is essential for understanding the background for the events surrounding Galileo's trial. The protestant Swedish king Gustavus Adolphus was routing the catholic Habsburgs on the battlefields of Germany until the situation came to a head in 1632 when he seemed to threaten Rome itself.

The pope Urban 8 was faced with a situation close to a coup d'etat vis-a-vis a group of cardinals led by the Spanish ambassador. At this point in time the pope was forced to reorient his policies away from the French who had been allied with the Swedes, and toward the Spanish, with the jesuits gaining greatly in influence.

At the same time Galileo's fortunes sank. The ascendancy of the jesuits was manifest by the 1633 trial of Galileo (see Section 4.5), formerly a protégé of the pope, and the active suppression of anything related to atomism or indivisibles.

That this occurred in the first few years of Fermat's creative mathematical activity may well have influenced his presentation of the method of maxima and minima and the method of tangents, particularly in view of sinister tensions with transubstantiation; see Section 5.2. Such issue may have also influenced the presentation of James Gregory's and degli Angeli's work, as we argue in Sections 4.6 and 4.7.

4.5. Scheiner vs Galileo. The trial of Galileo was provoked most likely by a denunciation from jesuit C. Scheiner (see [Festa 1991]) who could not conceal his glee at the verdict [Festa 1991, p. 109]. Assuming Scheiner was the source of the denunciation, Festa argues against Redondi's thesis that the atomism/eucharist issue was the hidden agenda of the Galileo trial. Festa offers two objections among others:

(1) given that the G3 denunciation (see Section 4.8) dates from around 1624, the Inquisition would not have delayed issuing a summons until as late as 1632 if the real issue were G3 and atomism/eucharist; and

(2) if on the other hand the denunciation originated with Scheiner, the hidden agenda hypothesis becomes implausible in view of 
Scheiner's apparent admiration for Gassendi and his book based on atomist theses.

Both of these objections, however, are answered in Redondi's book itself. As far objection (1) is concerned, the proceedings against Galileo were not initiated earlier because the pope was opposed to the idea, and the jesuits were too weak to impose them until the dramatic turn of historical events in 1632 (see Section 4.4). As far as objection (2) is concerned, even if Scheiner personally were not bothered by atomism, many others in Rome were (including the author of the EE291; see below), and the atomism/eucharist issue would have been a natural one to include in the indictment.

As far as the present article is concerned, what is relevant is that all agree that

les prises de position des jésuites contre l'atomisme au XVII ${ }^{\mathrm{e}}$ siècle n'avaient pas attiré jusqu'ici l'attention de beaucoup d'historiens. C'est avec la découverte du 'G3' et la parution du livre de Redondi qu'un intérêt pour ce problème s'est manifesté [Festa 1991, p. 116].

The subsequent discovery of the EE291 denunciation makes irrelevant Festa's objection (11) and lends support to Redondi's hypothesis; see Section 4.10 .

4.6. Degli Angeli in Italy. The jesuat mathematician degli Angeli defended the method of indivisibles against the criticisms of jesuit scholars. Less cautious than Cavalieri, in his rebuttal of Tacquet's criticism degli Angeli wrote:

"... if in order to approve the method of indivisibles, the composition of the continuum from indivisibles is necessarily required, then certainly this doctrine [i.e., continuum made out of indivisibles] is only strengthened in our eyes" (degli Angeli as translated in [Alexander 2014, p. 169-170]; cf. [Festa 1992, p. 205]).

Both indivisibles and degli Angeli himself appear to have been controversial at the time in the eyes of the jesuit order, which on several occasions banned indivisibles from being taught in their colleges. We already mentioned in Section 3.2 that in 1632 (the year Galileo received summons to stand trial over heliocentrism) the Society's Revisors General led by Jakob Bidermann banned teaching indivisibles in their colleges [Festa 1990], [Festa 1992, p. 198, 207]. In 1651 indivisibles were placed on the Society's list of permanently banned doctrines Hellyer 1996. 
4.7. Gregory's departure from Italy. It seems that James Gregory's 1668 departure from Padua was well timed. Indeed, his teacher degli Angeli's jesuat order (to which Cavalieri had also belonged) was not treated with clemency but on the contrary suppressed by papal brief of Clement 9 in the same year. Alexander describes the suppression as "stunningly violent" Alexander 2014, p. 171]. The suppression cut short degli Angeli's output on indivisibles. Gregory's own books were suppressed at Venice, according to a letter from John Collins to Gregory dated 25 november 1669, in which he writes:

One Mr. Norris a Master's Mate recently come from Venice, saith it was there reported that your bookes were suppressed, not a booke of them to be had anywhere, but from Dr. Caddenhead to whom application being made for one of them, he presently sent him one (though a stranger) refusing any thing for it. Turnbull, 1939, p. 74]

In a 1670 letter to Collins, Gregory writes:

I shall be very willing ye writ to Dr Caddenhead in Padua, for some of my books. In the mean time, I desire you to present my service to him, and to inquire of him if my books be suppressed, and the reason thereof. (Gregory to Collins, St Andrews, march 7, 1670, in Turnbull p. 88)

This passage indicates that Gregory sought an explanation for the suppression of his books. We are not aware of any clarification he may have received on this issue. In a letter to Gregory, written in London on 29 september 1670, Collins wrote:

Father Bertet 34 sayth your Bookes are in great esteeme, but not to be procured in Italy. (Turnbull p. 107)

The publishers' apparent reluctance to get involved with Gregory's books may also explain degli Angeli's silence on indivisibles following the suppression of his order, but it is hard to say anything definite in the matter until the archives at the Vatican dealing with the suppression of the jesuat order are opened to independent researchers. Certainly one can understand Gregory's own caution in the matter of exploiting the infinitely small. Nonetheless, Gregory exploited some identifiably infinitary procedures in his work; see [Bascelli et al. 2018].

\footnotetext{
${ }^{34}$ Jean Bertet (1622-1692), jesuit, quit the Order in 1681. In 1689 Bertet conspired with Leibniz and Antonio Baldigiani in Rome to have the ban on Copernicanism lifted. Wallis 2012
} 
Beyond the borders of a catholic Italy, John Wallis introduced the symbol $\infty$ for an infinite number in his book Arithmetica Infinitorum Wallis 1656], and exploited an infinitesimal number of the form $\frac{1}{\infty}$ in area calculations [Scott 1981, p. 18], over a decade before the publication of Gregory's Vera Circuli. At about the same time, Barrow "dared to explore the logical underpinnings of infinitesimals:"

Barrow, who dared to explore the logical underpinnings of infinitesimals, was certainly modern and innovative when he publicly defended the new mathematical methods against Tacquet and other mathematical "classicists" reluctant to abandon the Aristotelian continuum. And after all, to use historical hindsight, it was the nonArchimedean structure of the continuum linked to the notion of infinitesimal and advocated by Barrow that was to prove immensely fruitful as the basis for the Leibnizian differential calculus. [Malet 1989, p. 244].

On the other side of the Channel, Wallis and Barrow were freer than degli Angeli and Fermat to pursue the infinitely small.

The international nature of the jesuit organisation could not but affect what can or cannot be said in catholic France. Fermat's friend Lalouvère at Toulouse was both a jesuit and a mathematician opposed to indivisibles. Lalouvère actively interacted with Fermat in matters mathematical and would surely serve as a reminder should Fermat think of engaging in activities (such as any explicit endorsement of Cavalieri's doctrines) the jesuits considered objectionable.

4.8. Council of Trent, Galileo, and G3. An anonymous denunciation of Galileo, labeled G3, dating from the 1620s and preserved in the Vatican archives specifically connects Galileo's atomism to an "error condemned by" the Council of Trent Session 13, canon 2. The G3 document stated:

... one will also have to say according to this doctrine that there are the very tiny particles with which the substance of the bread first moved our senses, which if they were substantial (as Anaxagoras said, and this author [i.e., Galileo] seems to allow on page 200, line 28), it follows that in the Sacrament there are substantial parts of bread or wine, which is the error condemned by the Sacred Tridentine Council, Session 13, Canon 2. (G3 cited in [Redondi 1987, p. 334]) 
Having earlier mentioned the atomic theories of Anaxagoras and Democritus (ancient authorities espousing atomism), the author of G3 goes on to impute to Galileo an alignment with Democritus:

Or actually, if they were only sizes, shapes, numbers, etc., as he [i.e., Galileo] also seems clearly to admit, agreeing with Democritus, it follows that all these are accidental modes, or, as others say, shapes of quantity. (ibid.)

This passage indicates that Galileo's science, allegedly following the atomism of Democritus, was viewed as a threat to canon 13.2 related to one of the disagreements between Rome and the protestants (see Section 4.10), and was therefore controversial.

Galileo held that sensible qualities (color, taste, etc.) existed in minds, but not in bodies; they were, in Galileo's phrase, "nothing but names so far as the object in which we place them is concerned," with no necessary connection to properties in bodies. Meanwhile catholic doctrine held that a miracle was necessary to preserve the color, taste, etc. of the host after it had been miraculously changed to the body of the nazarene. Grassi pointed out the incompatibility of the two doctrines.

4.9. Document EE291 on Galileo's atomism. In 1999 Mariano Artigas discovered an additional anonymous denunciation of Galileo. The new document is labeled EE291 and dates from 1632. The issue is again incompatibility with the eucharist. The author of EE291 is thought to be the jesuit Melchior Inchofer. The criticisms voiced in G3 were echoed in Inchofer's 1632 denunciation EE291 in the following terms:

2. [Galileo] errs when he says that it is not possible to conceptually separate corporeal substances from the accidental properties that modify them, such as quantity and those that follow quantity. Such an opinion is absolutely contrary to faith, for instance in the case of the eucharist, where quantity is not only really distinguished from substance but, moreover, exists separately.

3. He errs when he says that taste, smell, and colour are pure names, etc.

(as cited in Artigas et al. 2005)

The denunciation was filed in 1632 only a few months before Galileo received summons to stand trial. 
4.10. Concerning Canon 13.2. In 1551 the said canon stipulated:

CANON II. If any one saith, that, in the sacred and holy sacrament of the eucharist, the substance of the bread and wine remains conjointly 35 with the body and blood of [the nazarene], and denieth that wonderful and singular conversion of the whole substance of the bread into the Body, and of the whole substance of the wine into the Blood-the species Only of the bread and wine remaining-which conversion indeed the Catholic Church most aptly calls Transubstantiation; let him be anathema. (Council of Trent, Session 13) (emphasis added)

The Council of Trent said nothing of mathematical indivisibles, but the jesuits interpreted 13.2 as anathemizing both physical and mathematical indivisibles, a distinction they may not have drawn. Whether they did or not is irrelevant for our purposes.

It is less than apparent why this canon entails the condemnation of indivisibles, so a word of explanation is in order. The key to understanding the conflict between Galilean atoms and 13.2 is the adverb conjointly ("una cum" in the original), which alludes to the doctrine of consubstantiation, one of the alternatives to transubstantiation. According to consubstantiation, the doctrine condemned by Aquinas as heresy but favored by Luther, the substance of the bread and the substance of the nazarene's body are present together in the eucharist.

In transubstantiation, by contrast, the substance of the bread is changed by a miracle into the substance of the nazarene's body; see [McCue 1968] for details. Now, Galileo's atomism holds that the sensible qualities of the bread are no more than the effect of the atoms of the bread acting upon the sense organs; i.e., they are not qualities of the bread itself. Since it is inconceivable that the faithful should be deceived through sensations that correspond to nothing real in the eucharist, the atomist must insist that the atoms of bread continue to exist consubstantially, i.e. together with the body of the nazarene, to cause those sensations; see Chareix 2002 for details.

\footnotetext{
35 "panis et vini una cum corpore et sanguine" in the original Latin. This is the key term here - this is the doctrine favored by Luther - consubstantiation. It was favored also by Scotus and Ockham, who rejected it only because it was inconsistent with the 1215 Lateran council. Artigas et al. note that "the concept of substance [in 13.2] was borrowed from Aristotelian philosophy" Artigas et al. 2005. The substance/form dichotomy is the content of the Aristotelian doctrine of hylomorphism.
} 
Galileo's critic, Grassi, scoffed that for the preservation of mere names no miracle would be required A 36 condemnation of atomism as subversive of the eucharist was issued by jesuit Sforza Pallavicino [Festa 1991, p. 115]; [Festa 1992, p. 203]. A further denunciation was issued in 1632; see Section 4.9,

4.11. Old and new heresy. Incompatibility with canonical doctrine was not merely a theoretical issue. Thus, David Derodon's book was burned as the result of a denunciation and pressure exerted by the jesuits [Redondi 1987, p. 274]. Derodon's 1655 book, Dispute sur l'Eucharistie, affirmed the spiritual presence over the real presence of the nazarene (ibid.). Redondi refers to it as the old heresy; this was first codified in 1079 by the synod of Rome.

Another illustration of the inherent dangers of publication may have been familiar to Fermat through his friendship with the d'Espagnets. Jean d'Espagnet collected scientific manuscripts and eventually passed on his library to his son Etienne. Jean wrote a book on alchemy under a pseudonym because in the atmosphere of the counterreformation it may have been dangerous to publish it under his own name [Willard 1999, p. xxii]. Fermat first became acquainted with the work of Vieta through this private library in Bordeaux in the late 1620s. Many of Fermat's manuscripts were deposited with Etienne d'Espagnet for safekeeping and eventually reached Mersenne.

Fermat may well have come to the conclusion that publishing books was too risky, and chose a safer method of disseminating his discoveries through private letters and manuscripts. The fate of alchemists imprudent enough to publish under their real names in the 1620s is analyzed in Kahn 2002].

Atomism and indivisibles were seen by some in the catholic hierarchy, including Grassi, the author of G3, Inchofer, and others, as a threat to the said canon 13.2 .

4.12. Reception of Galileo trial in France. Lewis's monograph [Lewis 2006] analyzes the reception of the Galileo trial in France, while the monograph Palmerino-Thijssen 2004 presents a broader European perspective. The salient points for us concern Fermat's correspondents in Paris, Carcavy and Mersenne. Marin Mersenne contributed in a major way to the diffusion of Galileo's ideas in France Lewis 2006,

\footnotetext{
${ }^{36}$ Grassi's objections (see [Festa 1991, pp. 100-101]) closely parallel those contained in G3, leading Redondi to conjecture that Grassi was in fact the author of G3. Many Galileo scholars, however, feel that there is insufficient evidence for this, and specifically reject Redondi's claim of similarity of handwriting. See Section 4.5 for further details.
} 
Chapter 5]; see also [Palmerino-Thijssen 2004, p. 36]. Carcavy sought to help Galileo disseminate his works [Lewis 2006, Chapter 4]; see also Palmerino-Thijssen 2004, p. 38].

Fermat's letter to Mersenne indicates that Fermat possessed a copy of Galileo's Due Nuove Scienze as early as 10 august 1638 [Lewis 2006, p. 137]. Fermat was involved in discussions of Galileo's science of motion, as we know from a letter from Pardies to Oldenburg:

"Father La Loubère came in on this and demonstrated that motion could perfectly well occur in the hypothesis of Father Cazré provided that the body did not pass through all degrees of slowness. In fact he claims that as the weight of a body is determined at a certain degree of force, this weight also pushes the body downwards with a certain degree of speed from the beginning of its fall; and this seemed so reasonable that Mr. Fermat himself found no fault with it." (quoted in Palmerino 2003, p. 217])

Here Father La Loubère is none other than Fermat's friend Lalouvère, enemy of indivisibles [Descotes 2015, p. 267], who appears to have discussed a variety of scientific subjects with Fermat.

Yet another Galileo-Fermat connection is analyzed in [Roberts 2011].

\section{Fermat at Castres and CONClusion}

Fermat was personally in charge of interdenominational issues as part of his professional responsibilities at the Parliament of Toulouse:

[Fermat] fait partie de la "Chambre de l'Édit", prévue par l'édit de Nantes pour juger paritairement des litiges entre catholiques et protestants. Il fut un homme de compréhension et de conciliation, au lendemain des guerres de religion. Féron 2002

Fermat acted as a representative of the Parliament of Toulouse to the Chambre de l'Édit in Castres in charge of conflicts involving Protestants and Catholics.

Fermat's official position as mediator may help explain his reticence to comment on issues, like the nature of his $E$ exploited in the method of adequality, that could have involved him in controversy over the canons; see Section 4.8 .

5.1. Jean de l'Hospital, (ancient) Conseiller. Jean de l'Hospital was Conseiller at the Parliament of Toulouse until 1562, when he was expelled "en raison de ses choix religieux" [Mouranche 2017, pp. 27-28]. 
Following the 1572 Bartholomew massacre [Mouranche 2017, p. 42], he became president of a judicial body (chambre mi-partie) that would move to Castres and eventually be transformed into the Chambre de l'Édit. According to historians who identify Claire de Long as Pierre de Fermat's mother 37 Jean de l'Hospital was his great-grandfather; see further in Section 5.4.

5.2. Fermat's poem. Fermat kept a safe distance away from the subject of con/transubstantiation (see Section 4.10) not only in his mathematics but also in his poetry. Fermat's poem was presented at the Academy of Castres (of which Fermat was not officially a member) in 1656 [Mouranche 2017, p. 60].

Fermat was inspired by Balzac's lucid writings on some arcane points of religious doctrine to attempt to do the same with regard to the events surrounding the execution of the nazarene. The resulting poem was meant to enlighten and inspire the faithful with regard to this central event of both catholic and protestant traditions. It would therefore have been natural to mention the eucharist as well in the poem. The fact that Fermat does not do so directly is significant.

Fermat's 101-line hexameter poem concerning the events leading up to the execution carefully steers away from the subject of the eucharist, which is however considered by Fermat's coreligionists to be central to the events in question. The execution is evoked at line 36, followed at lines 55-56 by a flashback to his companions falling asleep (after the supper when he reportedly uttered the words hoc est corpus, etc.), but there is no mention in the poem of hoc est corpus.

The related interdenominational tensions are well illustrated by the following passage penned by anglican archbishop John Tillotson in 1694: "In all probability those common juggling words of hocus pocus are nothing else but a corruption of hoc est corpus, by way of ridiculous imitation of the [catholic] priests ... in their trick of Transubstantiation." $" 38$

5.3. Academy of Castres. Further details on the Academy of Castres are provided by Spiesser:

... c'est surtout à Castres que se retrouvent nombre de correspondants et d'interlocuteurs de Fermat. Peut-être est-ce une des raisons pour lesquelles le magistrat affectionnait tout particulièrement d'y séjourner. Ce bastion de la religion réformée en albigeois, au début du

\footnotetext{
${ }^{37}$ See note 26,

${ }^{38}$ See also http://www.etymonline.com/index.php?term=hocus-pocus
} 
XVIIe siècle, accueille le Chambre de l'Edit entre 1632 et 1670; et ce sont les membres de cette Chambre, parmi lesquelles se trouvent beaucoup de huguenots, qui ont constitué les forces vives de l'Académie fondée en 1648 par Paul Pellisson, et dont les années florissantes se situent dans cette période. [Spiesser 2016, p. 292]

Spiesser continues with a more detailed description of Fermat's circle of acquaintances at Castres:

Le réseau castrais de Pierre de Fermat s'organise autour de l'Académie locale. Bien qu'à notre connaissance, il n'ait jamais été membre de cette institution, elle constitue la pierre de touche de ses alliances amicales et littéraires. L'avocat Pierre Saporta, membre de cette petite académie et traducteur du 'Traité sur la mesure des eaux courantes' du père bénédictain Benedetto Castelli, ainsi que d'un ouvrage de Torricelli sur le 'mouvement des eaux', admire Fermat. (ibid.)

Given that Fermat's main professional occupation as Conseiller at the Parliament of Toulouse and its Chambre de l'édit at Castres involved delicate matters of interdenominational dialogue, Fermat could hardly have allowed himself to get involved in anything related to issues of controversy dividing the different and sometimes warring (see Section 4.4) communities, such as the issues of transubstantiation and its potential tensions with atomism (and, by implication, with indivisibles and the infinitely small), seen at the time as potentially contrary to canon established at the Council of Trent in the previous century, with dire consequences for failing to toe the canonical line.

5.4. The lesson of the Marranos of Toulouse. A case in point (of failing to toe the canonical line) is the tale of 18 Toulouse Marranos, judged by the honorable judge de Fermat fils among others and sentenced in 1685. The Marranos escaped in time and only their effigies were burned in absentia in 1692: "Les accusés ont eu raison de s'enfuir. Toulouse les aurait certainement envoyés au bûcher." 39 [Blamont 2000, p. 352].

When Pierre Fermat was a teenager, Lucilio Vanini (1585-1619) was executed at Toulouse on charges of blasphemy [Mouranche 2017, p. 62].

\footnotetext{
39"The accused were right to flee. Toulouse would have certainly sent them to the stake." One of the 18 Marranos, named Roque de Leon, was an ancestor of Jacques Blamont; see [Blamont 2000, p. 17].
} 
No Conseiller other than Pierre de Fermat of the Parliament of Toulouse was interested in mathematics and no member in the protestant academy of Castres was a mathematician, but a rumor of dubious dealings in consubstantial natural philosophy may well have ruined Fermat, who had his share of enemies at the Parliament, including the President Fieubet 40 To put in bluntly, the honorable judge Pierre de Fermat risked ending up on the wrong side of the bench (or suffering the fate of his great-grandfather; see Section 5.1) had he pursued those exceedingly little devils with excessive zeal.

The infinitely small were seen as inseparable from atomism, which was seen as heretical because it contradicted canon 13.2 of the Council of Trent, which was one of the major issues dividing catholics and protestants, so much so that books and people were burned over this.

In a more liberal milieu, mathematicians like Wallis, Barrow, and Huygens felt freer to speak of, and indeed freely spoke of, the infinitely small, resuming the discussion where the once-flourishing Italian school had left it.

\section{ACKNOWLEDGMENTS}

We are grateful to Catherine Goldstein, Israel Kleiner, Eberhard Knobloch, David Schaps, and Maryvonne Spiesser for helpful comments. We thank Thomas Willard for the information on Fludd and Kepler given in note 11. M. Katz was partially supported by the Israel Science Foundation grant no. 1517/12.

\section{REFERENCES}

[Alexander 2014] (2014). Alexander, A. Infinitesimal: How a Dangerous Mathematical Theory Shaped the Modern World. New York: Farrar, Straus and Giroux.

[Andersen 1983] (1983). Andersen, K. The mathematical technique in Fermat's deduction of the law of refraction. Historia Mathematica, 10(1), 48-62.

\footnotetext{
${ }^{40}$ We find the following period detail: “...l'intendant du Languedoc, Claude Bazin de Bezons, a émis en 1663 un jugement aussi lapidaire que péjoratif sur son [Fermat's] activité de magistrat. Dans une note adressée au ministre Colbert sur les membres du parlement de Toulouse, il déclare que Fermat est 'homme de beaucoup d'érudition, a commerce de tous costés avec des sçavans, mais assez intéressé, n'est pas trop bon rapporteur et est confus"' Mouranche 2017, p. 52]. Bazin added that Fermat "n'est pas des amys du premier président" (ibid.), namely Gaspard de Fieubet. President Fieubet overruled Fermat in the matter of the priest Raymond Delpoy and had Delpoy hanged. "Fermat, qui n'était pas convaincu de sa culpabilité, en fut choqué" (ibid.).
} 
[Artigas et al. 2005] (2005). Artigas, M., Martínez, R., \& Shea, W. New light on the Galileo affair? In The Church and Galileo, Ernan McMullin, Ed. Notre Dame: University of Notre Dame Press, pp. 213-233.

[Bair et al. 2017] (2017). Bair, J., Błaszczyk, P., Ely, R., Henry, V., Kanovei, V., Katz, K., Katz, M., Kutateladze, S., McGaffey, T., Reeder, P., Schaps, D., Sherry, D., \& Shnider, S. Interpreting the infinitesimal mathematics of Leibniz and Euler. Journal for General Philosophy of Science, 48(2) (2017), 195-238. See http://dx.doi.org/10.1007/s10838-016-9334-z and http://arxiv.org/abs/1605.00455

[Barner 2011] (2011). Barner, K. Fermats 'adaequare' - und kein Ende? Mathematische Semesterberichte, 58(1), 13-45.

[Bascelli 2014a] (2014a). Bascelli, T. Galileo's quanti: understanding infinitesimal magnitudes. Archive for History of Exact Sciences, 68(2), 121-136.

[Bascelli 2014b] (2014b). Bascelli, T. Infinitesimal issues in Galileo's theory of motion. Revue Roumaine de Philosophie, 58(1), 23-41.

[Bascelli et al. 2014] (2014). Bascelli, T., Bottazzi, E., Herzberg, F., Kanovei, V., Katz, K., Katz, M., Nowik, T., Sherry, D., \& Shnider, S. Fermat, Leibniz, Euler, and the gang: The true history of the concepts of limit and shadow. Notices of the American Mathematical Society, 61(8), 848-864.

See http://www.ams.org/notices/201408/rnoti-p848.pdf and https://arxiv.org/abs/1407.0233

[Bascelli et al. 2016] (2016). Bascelli, T., Błaszczyk, P., Kanovei, V., Katz, K., Katz, M., Schaps, D., \& Sherry, D. Leibniz vs Ishiguro: Closing a quartercentury of syncategoremania. HOPOS: Journal of the Internatonal Society for the History of Philosophy of Science, 6(1), 117-147.

See http://dx.doi.org/10.1086/685645 and http://arxiv.org/abs/1603.07209

[Bascelli et al. 2017] (2017). Bascelli, T., Błaszczyk, P., Borovik, A., Kanovei, V., Katz, K., Katz, M., Kutateladze, S., McGaffey, T., Schaps, D., \& Sherry, D. Cauchy's infinitesimals, his sum theorem, and foundational paradigms. Foundations of Science, 22. See http://dx.doi.org/10.1007/s10699-017-9534-y and https://arxiv.org/abs/1704.07723

[Bascelli et al. 2018] (2018). Bascelli, T., Błaszczyk, P., Kanovei, V., Katz, K., Katz, M., Kutateladze, S., Nowik, T., Schaps, D., \& Sherry, D. Gregory's sixth operation. Foundations of Science, 23.

See http://dx.doi.org/10.1007/s10699-016-9512-9 and https://arxiv.org/abs/1612.05944

[Blamont 2000] (2000). Blamont, J. Le lion et le moucheron. Histoire des Marranes de Toulouse. Paris: Odile Jacob.

[Błaszczyk et al. 2017] (2017). Błaszczyk, P., Kanovei, V., Katz, K., Katz, M., Kutateladze, S., \& Sherry, D. Toward a history of mathematics focused on procedures. Foundations of Science, 22(4). See http://dx.doi.org/10.1007/s10699-016-9498-3 and https://arxiv.org/abs/1609.04531

[Bosmans 1927] (1927). Bosmans, H. André Tacquet (S. J.) et son traité d' 'Arithmétique théorique et pratique.' Isis, 9(1), 66-82.

[Boyer 1949] (1949). Boyer, C. The concepts of the calculus. New York: Hafner Publishing Company. 
[Breger 1994] (1994). Breger, H. The mysteries of adaequare: a vindication of Fermat. Archive for History of Exact Sciences, 46(3), 193-219.

[Breger 2013] (2013). Breger, H. Fermat's analysis of extreme values and tangents. Studia Leibnitiana, 45(1), 20-41.

[Chabbert 1967] (1967). Chabbert, P. Fermat à Castres. Revue d'Histoire des Sciences et de leurs Applications, 20, 337-348.

[Chareix 2002] (2002). Chareix, F. Il Saggiatore. In Le Mythe Galilée, Paris, Presses Univrsitaire de France, 109-121.

[Cifoletti 1990] (1990). Cifoletti, G. La méthode de Fermat: son statut et sa diffusion. Algèbre et comparaison de figures dans l'histoire de la méthode de Fermat. Cahiers d'Histoire et de Philosophie des Sciences. Nouvelle Série 33. Paris: Société Française d'Histoire des Sciences et des Techniques.

[De Ceglia 2003] (2003). De Ceglia, F. Additio illa non videtur edenda: Giuseppe Biancani, reader of Galileo in an unedited censored text. In The new science and Jesuit science: seventeenth century perspectives, 159-186, Archimedes, 6, Kluwer Acad. Publ., Dordrecht.

[De Gandt 1992] (1992). De Gandt, F. L'évolution de la théorie des indivisibles et l'apport de Torricelli. In Geometry and atomism in the Galilean school, 103118, Bibl. Nuncius Studi Testi, X, Olschki, Florence.

[Descotes 2015] (2015). Descotes, D. Two Jesuits Against the Indivisibles. Chapter 11 in Jullien [Jullien 2015], 249-273.

[Feingold 2003] (2003). Feingold, M. Jesuits: savants. In Jesuit science and the republic of letters, 1-45, Transformations: Studies in the History of Science and Technology, MIT Press, Cambridge, MA.

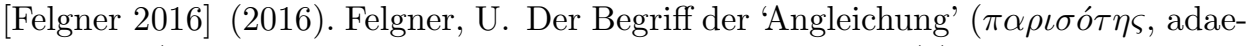
quatio) bei Diophant und Fermat. Sudhoffs Archiv, 100(1), 83-109.

[Fermat 1638] (1638). Fermat, P. Letter to Mersenne dated 20 april 1638. In Tannery-Henry Fermat 1894, 135-138.

[Fermat 1679] (1679). Fermat, P. Varia opera mathematica di Petri de Fermat. Toulouse: Pech.

[Fermat 1891] (1891). Fermat, P. Oeuvres de Fermat, Vol. 1. P. Tannery and C. Henry, Eds., Paris: Gauthier-Villars.

[Fermat 1894] (1894). Fermat, P. Oeuvres de Fermat, Vol. 2. P. Tannery and C. Henry, Eds., Paris: Gauthier-Villars.

[Fermat 1896] (1896). Fermat, P. Oeuvres de Fermat, Vol. 3. P. Tannery and C. Henry, Eds., Paris: Gauthier-Villars.

[Fermat 1912] (1912). Fermat, P. Oeuvres de Fermat, Vol. 4. Compléments par M. Charles Henry. P. Tannery and C. Henry, Eds. Paris: Gauthier-Villars, 1912.

[Fermat 1922] (1922). Fermat, P. Oeuvres de Fermat: Supplément aux tomes I-IV, documents inédits publiés avec notices sur les nouveaux manuscrits par M. C. De Waard, Paris: Gauthier-Villars, 1922.

[Féron 2002] (2002). Féron, P., Ed. Pierre de Fermat un génie européen. Toulouse: Presses de l'Université des Sciences Sociales. http://www.ut-capitole.fr/recherche/publications-de-l-universite/presses-de-l-universite

[Festa 1990] (1990). Festa, E. La querelle de l'atomisme: Galilée, Cavalieri et les Jésuites. La Recherche (sept. 1990), 1038-1047. 
[Festa 1991] (1991). Festa. E. Galilée hérétique? Revue d'Histoire des Sciences, 44(1) (janvier-mars 1991), 91-116.

[Festa 1992] (1992). Festa, E. Quelques aspects de la controverse sur les indivisibles. In Geometry and atomism in the Galilean school, 193-207, Bibl. Nuncius Studi Testi, X, Olschki, Florence.

[Festa et al. 1999] (1999). Festa, E., Jullien, V., \& Torrini, M. (Eds.) Géométrie, atomisme et vide dans l'école de Galilée. Textes réunis par E. Festa, V. Jullien et M. Torrini. Firenze - Fontenay et Saint-Cloud: Istituto e museo di storia délia scienza - ENS éd.

[Fletcher et al. 2017] (2017). Fletcher, P., Hrbacek, K., Kanovei, V., Katz, M., Lobry, C., \& Sanders, S. Approaches to analysis with infinitesimals following Robinson, Nelson, and others. Real Analysis Exchange 42(2), 193-252.

See https://arxiv.org/abs/1703.00425 and http://msupress .org/journals/issue/?id=50-21D-61F

[Gairin 2001] (2001). Gairin P. Pierre Fermat et ses ascendants. Publié à compte d'auteur, Beaumont-de-Lomagne.

[Gerhardt 1850] (1850-1863). Gerhardt, C. I., Ed. Leibnizens mathematische Schriften. Berlin and Halle: Eidmann.

[Hellyer 1996] (1996). Hellyer, M. 'Because the Authority of my Superiors Commands': Censorship, Physics and the German Jesuits. Early Science and Medicine, 1(3), 319-354.

[Hérigone 1642] (1642). Hérigone, P. Cursus mathematicus, vol 6: Supplementum Cursus mathematici, Paris.

[Herzberg et al. 2018] (2018). Herzberg, F., Kanovei, V., Katz, M., \& Lyubetsky, V. Minimal axiomatic frameworks for definable hyperreals with transfer. Journal of Symbolic Logic. See http://dx.doi.org/10.1017/jsl.2017.48 and https://arxiv.org/abs/1707.00202

[Ingegno 2002] (2002). Ingegno, A. Review of Festa et al. [Festa et al. 1999]. Revue d'Histoire des Sciences, 55(2), Etudes sur l'atomisme (XVIe-XVIIe siècles) (avril-juin 2002), 312-318.

[Jongmans 2008] (2008). Jongmans, F. In vino veritas, in dolio calamitas. With an appendix by E. Seneta. The Mathematical Scientist 33(1), 1-7.

[Jullien 2015] (2015). Jullien, V., Ed. Seventeenth-Century Indivisibles Revisited. Science Networks. Historical Studies 49, Springer International Publishing, Switzerland.

[Kahn 2002] (2002). Kahn, D. La condamnation des thèses d'Antoine de Villon et Etienne de Clave contre Aristote, Paracelse et les 'cabalistes' (1624). Revue d'histoire des sciences 55(2), Etudes sur l'atomisme (XVIe-XVIIe siècles) (avril-juin 2002), 143-198.

[Katz-Katz 2012] (2012). Katz, K., \& Katz, M. A Burgessian Critique of Nominalistic Tendencies in Contemporary Mathematics and its Historiography. Foundations of Science, 17(1), 51-89.

See http://dx.doi.org/10.1007/s10699-011-9223-1 and https://arxiv.org/abs/1104.0375

[Katz et al. 2013] (2013). Katz, M., Schaps, D., \& Shnider, S. Almost Equal: The Method of Adequality from Diophantus to Fermat and Beyond. Perspectives on Science, $21(3), 283-324$.

See http://www.mitpressjournals.org/doi/abs/10.1162/P0SC_a_00101 
and http://arxiv.org/abs/1210.7750

[Katz-Sherry 2013] (2013). Katz, M., \& Sherry, D. Leibniz's infinitesimals: Their fictionality, their modern implementations, and their foes from Berkeley to Russell and beyond. Erkenntnis, 78(3), 571-625.

See http://dx.doi.org/10.1007/s10670-012-9370-y and http: //arxiv.org/abs/1205.0174

[Kock 2006] (2006). Kock, A. Synthetic differential geometry. Second edition. London Mathematical Society Lecture Note Series, 333. Cambridge: Cambridge University Press.

[Koyré 1954] (1954). Koyré, A. Bonaventura Cavalieri et la géométrie des continus. In Etudes d'histoire de la pensée scientifique, Gallimard, 1973. Originally published in Hommage à Lucien Febvre, Colin, Paris, 1954.

[Leibniz 1699] (1699). Leibniz, G. Letter to Wallis, 30 march 1699, in Gerhardt (GM) Gerhardt 1850, vol. IV, p. 62-65].

[Lewis 2006] (2006). Lewis, J. Galileo in France: French Reactions to the Theories and Trial of Galileo. Currents in Comparative Romance Languages and Literatures, vol. 109. New York: Peter Lang.

[Mahoney 1973] (1973). Mahoney, M. The mathematical career of Pierre de Fermat. Princeton, NJ: Princeton University Press.

[Mahoney 1994] (1994). Mahoney, M. The mathematical career of Pierre de Fermat, 1601-1665. Second edition. Princeton Paperbacks. Princeton, NJ: Princeton University Press.

[Malet 1989] (1989). Malet, A. Studies on James Gregorie (1638-1675). Thesis (Ph.D.) Princeton University.

[Mancosu 1996] (1996). Mancosu, P. Philosophy of mathematics and mathematical practice in the seventeenth century. The Clarendon Press, Oxford University Press, New York.

[Massa 1997] (1997). Massa, M. Mengoli on 'quasi proportions'. Historia Mathematica, 24(3), 257-280.

[McCue 1968] (1968). McCue, J. The Doctrine of Transubstantiation from Berengar through Trent: The Point at Issue. The Harvard Theological Review, 61, $385-430$.

[Mouranche 2017] (2017). Mouranche, M. (dir.) Pierre de Fermat l'énigmatique. Toulouse, Université fédérale Toulouse Midi-Pyrénées, Editions midipyrénéennes.

[Mousnier 1971] (1971). Mousnier, R. La Vénalité des offices sous Henri IV et Louis XIII. Paris: Presses universitaires de France.

[Noël-Trompler 2003] (2003). Noël, G., \& Trompler, S. Vers les infiniment petits. SBPMef (Société Belge des Professeurs de Mathématique d'expression française), p. 108-113.

[Palmerino 2003] (2003). Palmerino, C. Two Jesuit responses to Galileo's science of motion: Honore Fabri and Pierre Le Cazre. In The new science and Jesuit science: seventeenth century perspectives, 187-227, Archimedes, 6, Dordrecht: Kluwer Academic Publishers.

[Palmerino-Thijssen 2004] (2004). Palmerino, C., \& Thijssen, J. (eds.) The reception of the Galilean science of motion in seventeenth-century Europe. Boston Studies in the Philosophy of Science, 239. Dordrecht: Kluwer Academic Publishers. 
[Redondi 1987] (1987). Redondi, P. Galileo: heretic. Translated from the Italian by Raymond Rosenthal. Princeton, NJ: Princeton University Press.

[Roberts 2011] (2011). Roberts, B. How Galileo dropped the ball and Fermat picked it up. Synthese, 180, 337-356. See http://dx.doi.org/10.1007/s11229-009-9705-7

[Robinet 1991] (1991). Robinet, A. La conquête de la chaire de mathématiques de Padoue par les leibniziens. Revue d'Histoire des Sciences, 44(2), 181-201.

[Robinson 1966] (1966). Robinson, A. Non-standard analysis. Amsterdam: NorthHolland Publishing.

[Romano 1999] Romano, A. La Contre-Réforme mathématique. Constitution et diffusion d'une culture mathématique jésuite à la Renaissance (1540-1640). Bibliothèque des Écoles Françaises d'Athènes et de Rome [Library of the French Schools of Athens and Rome], 306. École Française de Rome, Rome, 1999.

[Scott 1981] (1981). Scott, J. The mathematical work of John Wallis, D.D., F.R.S. (1616-1703). Second edition. With a foreword by E. N. da C. Andrade. New York: Chelsea Publishing.

[Spiesser 2008] (2008). Spiesser, M. Pierre Fermat, profil et rayonnement d'un mathématicien singulier. In Mathématiciens français du XVIIe siècleDescartes, Fermat, Pascal, 167-197, Collection CERHAC. Clermont-Ferrand: Presses Universitaires Blaise-Pascal.

[Spiesser 2016] (2016). Spiesser, M. Pierre de Fermat, magistrat, philologue et mathématicien illustre (Beaumont-de-Lomagne, vers 1605-Castres, 1665). APMEP, 519, june 2016, 290-300.

[Strømholm 1968] (1968). Strømholm, P. Fermat's methods of maxima and minima and of tangents. A reconstruction. Archive for History Exact Sciences, 5(1), 47-69.

[Turnbull, 1939] (1939). Turnbull, H. James Gregory tercentenary memorial volume. Royal Society of Edinburgh. G. Bell and Sons, London.

[Unguru 1976] (1976). Unguru, S. Fermat revivified, explained, and regained. Francia, 4, 774-789.

[Wallis 1656] (1656). Wallis, J. Arithmetica Infinitorum. Oxford.

[Wallis 2012] (2012). Wallis, J. The correspondence of John Wallis. Vol. III (October 1668-1671). Edited by Philip Beeley and Christoph J. Scriba. Oxford: Oxford University Press.

[Weil 1973] (1973). Weil, A. Book Review: The mathematical career of Pierre de Fermat. Bulletin of the American Mathematical Society, 79(6), 1138-1149 (review of Mahoney Mahoney 1973).

[Weil 1978] (1978/79). Weil, A. Who betrayed Euclid? Extract from a letter to the editor. Archive for History of Exact Sciences, 19(2), 91-93.

[Weil 1984] (1984). Weil, A. Number theory. An approach through history. From Hammurapi to Legendre. Boston, MA: Birkhäuser.

[Willard 1999] (1999). Willard, T., Ed. Jean d'Espagnet's The Summary of Physics Restored: the 1651 Translation with D'Espagnet's Arcanum (1650). By Jean d'Espagnet. New York: Garland.

Jacques Bair is Professor Emeritus at the University of Liège (Belgium) who taught to students in economics and in management. He began as a specialist in convex geometry (see, for example, Springer 
Lecture Notes in Mathematics, N 489 and 802 by Bair and Fourneau). His present interests are epistemology and the teaching of mathematics. His most recent work concerns the foundations of mathematical analysis.

Mikhail G. Katz (BA Harvard '80; PhD Columbia '84) is Professor of Mathematics at Bar Ilan University, Ramat Gan, Israel. He observed a while ago that with Abraham Robinson's passing, the quest for the ghosts of departed quantifiers in the work of Fermat, Leibniz, Euler, and Cauchy began in earnest, as many a triumvirate scholar sought to transmogrify their infinitesimal procedures into proto-Weierstrassian hocus-pocus. He therefore resolved not to keep mum about it and with the help of coauthors who were adequal to the task, launched a decidedly nonstandard, long march through triumvirate historiography. While in the present article we examine the issue at stake with Fermat's method, we take a fresh look at Leibniz in [Bascelli et al. 2016], at Euler in [Bair et al. 2017], and at Cauchy in [Bascelli et al. 2017].

David Sherry is Professor of Philosophy at Northern Arizona University, in the tall, cool pines of the Colorado Plateau. He has research interests in philosophy of mathematics, especially applied mathematics and non-standard analysis. Recent publications include "Fields and the Intelligibility of Contact Action," Philosophy 90 (2015), 457-478. "Leibniz's Infinitesimals: Their Fictionality, their Modern Implementations, and their Foes from Berkeley to Russell and Beyond," with Mikhail Katz, Erkenntnis 78 (2013), 571-625. "Infinitesimals, Imaginaries, Ideals, and Fictions," with Mikhail Katz, Studia Leibnitiana 44 (2012), 166-192. "Thermoscopes, Thermometers, and the Foundations of Measurement," Studies in History and Philosophy of Science 24 (2011), 509-524. "Reason, Habit, and Applied Mathematics," Hume Studies 35 (2009), 57-85.

J. Bair, HEC-UlG, University of Liege, 4000 Belgium

E-mail address: J.Bair@ULiege.be

M. Katz, Department of Mathematics, Bar Ilan University, Ramat GAN 5290002 ISRAEL

E-mail address: katzmik@macs.biu.ac.il

D. Sherry, Department of Philosophy, Northern Arizona UniverSity, FlagstafF, AZ 86011, US

E-mail address: David.Sherry@nau.edu 